\title{
Sedimentation following the spring bloom in Disko Bay, West Greenland, with special emphasis on the role of copepods
}

\author{
Thomas Juul-Pedersen ${ }^{1,2}$, Torkel Gissel Nielsen ${ }^{1, *}{ }^{,}$Christine Michel ${ }^{2}$, \\ Eva Friis Møller ${ }^{1,3}$, Peter Tiselius ${ }^{4}$, Peter Thor ${ }^{4}$, Michael Olesen $^{5}$, Erik Selander ${ }^{4}$, \\ Saskia Gooding ${ }^{1}$

\begin{abstract}
${ }^{1}$ National Environmental Research Institute, Department of Marine Ecology, Frederiksborgvej 399, 4000 Roskilde, Denmark
${ }^{2}$ Freshwater Institute, Fisheries and Oceans Canada, 501 University Crescent, Winnipeg, Manitoba R3T 2N6, Canada ${ }^{3}$ University of Århus, Department of Marine Ecology, Finlandsgade 14, 8200 Århus, Denmark
\end{abstract} \\ ${ }^{4}$ Göteborg University, Department of Marine Ecology, Kristineberg Marine Research Station, 45034 Fiskebäckskil, Sweden \\ ${ }^{5}$ Copenhagen University, Zoological Institute, Marine Biological Laboratory, Strandpromenaden 5, 3000 Helsingør, Denmark
}

\begin{abstract}
The sedimentation of particulate organic material was investigated in Disko Bay, West Greenland, during June 2001. Post spring-bloom conditions were encountered, with seasonally decreasing phytoplankton biomass associated with the pycnocline. Calanus finmarchicus, C. glacialis, and $C$. hyperboreus dominated the zooplankton community, comprising up to $88 \%$ of the copepod biomass. Faecal pellet production by $C$. finmarchicus and C. glacialis was positively correlated to the available food (chlorophyll a $>10 \mu \mathrm{m}$ ). Results from short-term sediment trap deployments $(6 \mathrm{~h})$ showed that particulate organic carbon (POC) sedimentation from the euphotic zone was, on average, $628 \mathrm{mg} \mathrm{C} \mathrm{m}^{-2} \mathrm{~d}^{-1}$, with copepod faecal pellets contributing, on average, $29 \%$ of this amount. The faecal pellet contribution to the vertical sinking export of POC was equivalent to that of phytoplankton and amorphous detritus. Yet, on average, 35\% of the copepod faecal pellet production was retained within the euphotic zone. The POC:PON (particulate organic nitrogen) ratio of the suspended material in the euphotic zone $(8.1 \pm 0.4)$ was comparable to that of the material collected in the sediment traps just below the euphotic zone $(8.0 \pm 0.9)$. In addition, the daily loss rates of POC and PON within each sampling depth were similar, and the carbon to nitrogen ratio in the sediment traps did not change with depth. These results indicate that the pelagic system had a low retention efficiency of nitrogen just after the spring bloom.
\end{abstract}

KEY WORDS: Arctic marine ecology · Sedimentation · Faecal pellet production · Calanus spp. Carbon flux

Resale or republication not permitted without written consent of the publisher

\section{INTRODUCTION}

The single most important event of the annual plankton cycle in arctic and temperate waters is the spring phytoplankton bloom. The phytoplankton bloom develops in response to the increase in solar radiation during spring and upon stabilization of the water column. In temperate coastal waters the spring phytoplankton bloom takes place prior to the establishment of the mesozooplankton community. Consequently, a large part of the bloom sinks out of the euphotic zone ungrazed (Kiørboe \& Nielsen 1994, Olesen \& Lundsgaard 1995, Wassmann 1998). In contrast, deeper oceanic waters hosting an overwintering population of copepods, which can rapidly respond to the developing spring bloom, potentially exhibit a tight coupling between primary production and trophic transfer through the pelagic food web. Arctic pelagic ecosystems are characterized by large overwintering copepod populations dominated by Calanus spp., which are 
able to exploit the developing bloom (Hirche 1996, Madsen et al. 2001, Pasternak et al. 2001). Moreover, the large Calanus species also contribute to the vertical export of carbon from the euphotic zone by packaging organic material into large fast-sinking faecal pellets.

Sedimentation of phytoplankton from the euphotic zone is the principal mechanism in transporting organic material to the benthic communities in marine systems, either directly as intact cells or in the form of faecal pellets and amorphous detritus. During its transit to depth, the organic material produced in the euphotic zone is transformed by a range of processes that influence the quality and quantity of the sedimenting material that reaches the benthos (González \& Smetacek 1994, Olesen \& Lundsgaard 1995, Acuña et al. 1996, Kiørboe et al. 1996, Wassmann 1998).

The pelagic food web has been extensively studied in Disko Bay, West Greenland, during the last decade (Nielsen \& Hansen 1995, 1999, Levinsen et al. 2000a,b, Madsen et al. 2001, Levinsen \& Nielsen 2002). Previous studies primarily focused on the interactions between the different trophic levels in the pelagic food web. However, little is known about the vertical export of particulate organic material in this region. The Disko Bay area is an important fishing ground, especially for the northern shrimp (Pandalus borealis) and greenlandic halibut (Reinhardtius hippoglossoides) fisheries that are essential to the economy of Greenland (Buch et al. 2004). After their larval stage, both of these species feed on benthic invertebrates, and are therefore dependent on the quantity and quality of the

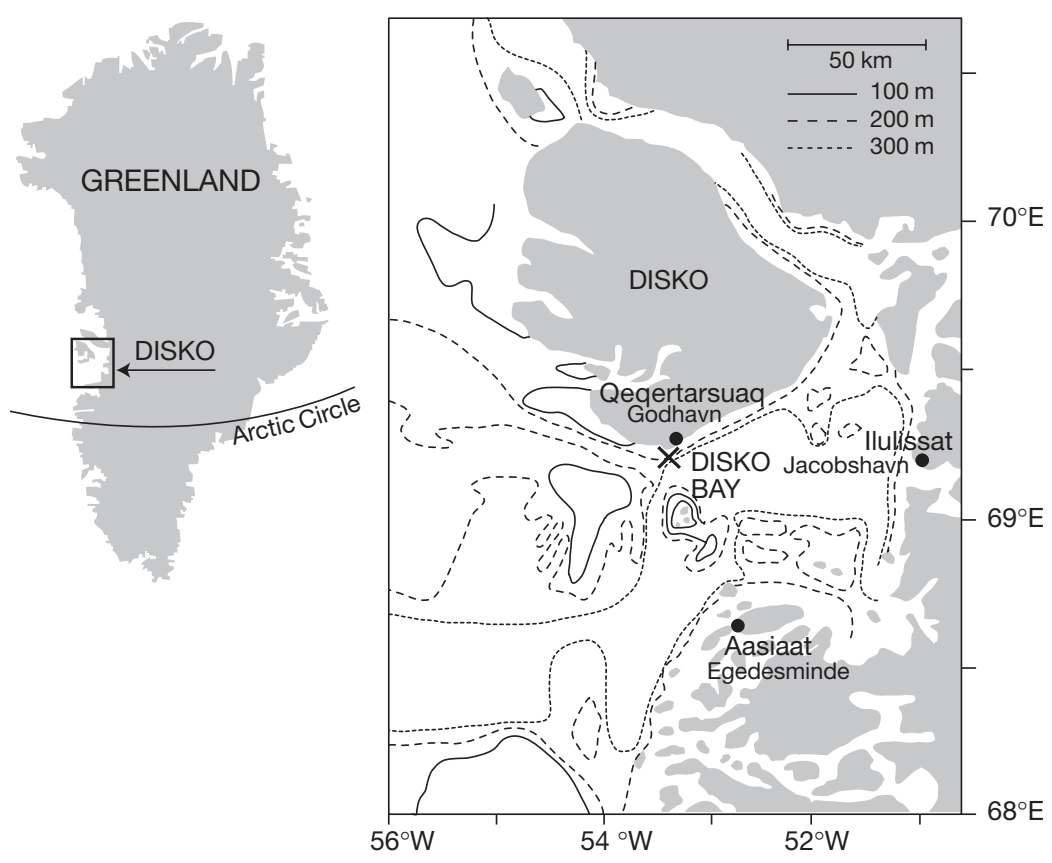

Fig. 1. Bathymetry of Disko Bay area and location of sampling station $(x)$ vertically exported organic material fuelling the benthic community. In this context, the grazing activity of the large copepods potentially play a key role, by accelerating the vertical export through production of large fast-sinking faecal pellets. This vertical export brings relatively high quality food to the benthic community. Thus far, this process has not been studied in West-Greenlandic waters.

In the present study, we present the first measurements of sedimentation rates of particulate organic material in the Disko Bay area. The aim of this study was to investigate the quantitative and qualitative aspects of the sedimentation following the spring bloom in Disko Bay, with special emphasis on the role of Calanus grazing activity in accelerating the vertical export of particulate organic material.

\section{MATERIALS AND METHODS}

Study site. The study was carried out at a $250 \mathrm{~m}$ deep station ca. 1 nautical mile (n mile) south of Qeqertarsuaq $\left(69^{\circ} 15^{\prime} \mathrm{N}, 53^{\circ} 33^{\prime} \mathrm{W}\right)$ in Disko Bay, West Greenland (Fig. 1). Sampling was conducted from June 1 to 23 (9 sampling dates), and took place from 10:00 to $16: 00 \mathrm{~h}$ during daily cruises to the station. In addition to the seasonal sampling, one diurnal study $(30 \mathrm{~h})$ was conducted from 10:00 h on June 10 to 16:00 h on June 11.

Sampling. Vertical profiles of water temperature, salinity and fluorescence were recorded down to $200 \mathrm{~m}$ using a Seabird SBE25-01-CTD equipped with a fluorometer (Chelsea). On the first sampling day (June 1), problems with the CTD probe demanded the use of a WTW salinity/temperature probe and a fluorometer (Dr. Hardt) instead. Salinity measurements were calibrated against salinity samples taken randomly throughout the investigation, and analyzed on a 8410-Portasal salinometer (Guildline). Light attenuation was measured in the upper $35 \mathrm{~m}$ of the water column using a photometer (Licor Quantum, model Li-192 SA, equipped with a spherical sensor). In situ fluorescence was calibrated against water column chlorophyll a (chl a) concentrations, which were determined fluorometrically. The following relationships were obtained: for the Dr. Hardt fluorometer, chl $a=$ (fluorescence $\times 1.08)-0.41, \mathrm{n}=41, \mathrm{r}^{2}=0.97, \mathrm{p}<$ 0.01 ; for the Chelsea fluorometer mounted on a Seabird CTD, chl $a=0.076 \times$ $\mathrm{e}^{1.68 \times \text { fluorescence }}, \mathrm{n}=64, \mathrm{r}^{2}=0.82, \mathrm{p}<0.01$. 
Sampling depths for chemical and biological variables were established according to water column structure. Sampling for suspended biomass and drifting sediment traps were carried out at corresponding depths $(15,35,50$, and $100 \mathrm{~m})$ and 2 additional depths were sampled for suspended biomass: surface $(5 \mathrm{~m})$ and the fluorescence maximum. After collection, the water samples were kept in dark and cold conditions during transport back to the laboratory, where subsamples were taken for further analyses.

The vertical export of particulate organic material was measured using drifting sediment traps which were deployed for ca. $6 \mathrm{~h}$ during each visit to the station (9 deployments). In addition, during the diurnal study (June 10 to 11), 1 set of sediment traps was deployed and recovered every $6 \mathrm{~h}$ (same deployment duration as during the seasonal sampling), while another set was deployed for a period of $24 \mathrm{~h}$. The drifting sediment trap array drifted from its initial position of deployment. However, sampling was always initiated at the same position. The average drift during the seasonal deployment periods was $1.3 \pm 0.3 \mathrm{n}$ mile (mean $\pm \mathrm{SE}, \mathrm{n}=8$ ) from the initial deployment position. The general drift path of the sediment trap array followed the depth contours in the area, so the depth remained fairly constant during the deployment.

The drifting sediment traps were fitted with a wavedampening device made of a large submerged primary floater $(1 \times 33 \mathrm{~kg}$ buoyancy), above which were 13 small floaters (13 $\times 1.7 \mathrm{~kg}$ buoyancy) of which only half were submerged. This array was designed so that water resistance on the submerged floaters and the rest of the array would reduce the vertical movement of the sediment traps relative to the waves.

The sediment traps (double sediment traps, KC Denmark) consisted of parallel acrylic cylinders mounted in a gimbaled frame equipped with a vane to ensure that the cylinders were always positioned vertically and perpendicular to the current. The traps were $0.33 \mathrm{~m}$ high and $0.052 \mathrm{~m}$ in diameter $(\mathrm{H}: \mathrm{D}=6.35)$. Prior to deployment, the traps were filled with $0.2 \mu \mathrm{m}$ filtered seawater with added brine to increase the salinity by 5 psu (Knap et al. 1996). After recovery, the traps were kept in the dark. The 2 traps from each depth were pooled before subsamples were taken for subsequent analyses at the laboratory (within $5 \mathrm{~h}$ of trap recovery). The sediment trap samples were visually checked for swimmers, but only on a few occasions were any found.

Water column and sediment trap samples were analyzed for several corresponding variables, using similar methods as described below, unless otherwise stated.

Primary production was measured in situ by incubating water samples collected at various depths with $4 \mu \mathrm{Ci} \mathrm{H}^{14} \mathrm{CO}_{3}^{-}$(International Agency for ${ }^{14} \mathrm{C}$ Determi- nation) during $2 \mathrm{~h}$ in 1 dark and 2 transparent $100 \mathrm{ml}$ Jena bottles (Nielsen \& Hansen 1995). After the incubation period, the bottles were kept in dark conditions and, within $1 \mathrm{~h}$, the contents were filtered onto $25 \mathrm{~mm}$ Whatmann GF/F filters. Inorganic ${ }^{14} \mathrm{C}$ was removed from the filters by adding $200 \mu \mathrm{l}$ of $1 \mathrm{~N} \mathrm{HCl}$ in scintillation vials. The samples were kept frozen until liquid scintillation counting on an LKB Wallac 1219 Rackbeta liquid scintillation counter. Further details on the method for measuring primary production will be found in T. G. Nielsen et al. (unpubl.).

Laboratory analyses. Size-fractionated chl a and phaeopigments (phaeo) (total and $>10 \mu \mathrm{m}$ ) were measured on $100 \mathrm{ml}$ duplicate subsamples filtered onto Whatmann GF/F and $10 \mu \mathrm{m}$ filters. The filters were then extracted in $96 \%$ ethanol (Jespersen \& Christoffersen 1987) and pigments were measured on a Turner $770 \mathrm{~h}$ fluorometer, calibrated against a chl a standard (chl $\mathrm{a}=0.069 \times$ fluorescence, $\mathrm{n}=27, \mathrm{r}^{2}=0.99, \mathrm{p}<0.01$ ), before and after acidification (Yentsch \& Menzel 1963, Strickland \& Parsons 1972).

Particulate organic carbon and nitrogen (POC and PON) were measured on pre-combusted Whatmann GF/F filters after filtration of 100 to $500 \mathrm{ml}$ of water column or sediment trap sample. The filters were kept frozen $\left(18^{\circ} \mathrm{C}\right)$ until returning to the laboratory in Denmark, where they were dried at $60^{\circ} \mathrm{C}$ for $24 \mathrm{~h}$ and kept frozen again until final analyses on a Carlo Erba Elemental Analyzer (EA 1108). The POC:PON ratios of the suspended and sedimenting material were calculated from a linear regression between the measured POC and PON values.

Faecal pellets were counted for both sediment traps and water column samples. For the sediment traps, faecal pellets were counted on $300 \mathrm{ml}$ subsamples, preserved with Lugol's solution (2\% final concentration). The size (width and length) of all faecal pellets was measured using a stereo light microscope (40× magnification, Olympus SZ40). For the water column, faecal pellets were counted and measured on freshly collected samples, using the same method as for the sediment traps. A number of 11 subsamples from the water column were concentrated on a $20 \mu \mathrm{m}$ sieve, rinsed back to a Petri dish and analyzed until a minimum of 30 pellets were counted and measured. Faecal pellet volumes were estimated using the size measurements and the characteristics of the faecal pellets (intact or broken), which were noted at the time of analyses. The volume of intact faecal pellets was calculated using the equation for a cylinder with halfspherical ends, and the volume of faecal pellet fragments was calculated using the equation for a cylinder. Faecal pellet volume was converted to biomass, using a carbon conversion factor of $69.4 \mu \mathrm{g} \mathrm{C} \mathrm{mm}^{-3}$ (Riebesell et al. 1995). 
POC was later divided into 3 fractions: chl a or phytoplankton based POC (PPC), faecal pellet based POC (FPC) and amorphous detritus based POC (amorphous detritus). The PPC fraction was estimated using the slope of the linear regression between chl $a$ and POC from the water column (see 'Water column' in 'Results'). The amorphous detritus fraction was estimated by subtracting the PPC and FPC fraction from the total POC.

Calculations. Sedimentation rate $\left(\mathrm{mg} \mathrm{m} \mathrm{m}^{-2} \mathrm{~d}^{-1}\right)$ was calculated using the following equation (Knap et al. 1996):

$$
\begin{gathered}
\text { Sedimentation rate }\left(\mathrm{mg} \mathrm{m} \mathrm{m}^{-2} \mathrm{~d}^{-1}\right)= \\
\left(C_{\text {trap }} \times V_{\text {trap }}\right) /\left(A_{\text {trap }} \times T_{\text {dep }}\right)
\end{gathered}
$$

where $C_{\text {trap }}\left(\mathrm{mg} \mathrm{m}^{-3}\right)$ is the concentration of the measured variable in the sediment trap, $V_{\text {trap }}$ is the volume of the sediment trap $\left(\mathrm{m}^{3}\right), A_{\text {trap }}$ is the sediment trap surface area $\left(\mathrm{m}^{2}\right)$ and $T_{\text {dep }}$ is the deployment time $(\mathrm{d})$.

Sinking velocity $\left(\mathrm{m} \mathrm{d}^{-1}\right)$ was estimated for different variables using the following equation (Kiørboe et al. 1994):

Sinking velocity $\left(\mathrm{m} \mathrm{d}^{-1}\right)=$ Sedimentation rate $/ C_{\text {in situ }}$

where the sedimentation rate is from Eq. (1) and $C_{\text {in situ }}$ $\left(\mathrm{mg} \mathrm{m}^{-3}\right)$ is the in situ concentration of the variables at the sediment trap depth.

The daily loss rate $\left(\% \mathrm{~d}^{-1}\right)$ of suspended material due to sedimentation was estimated using the following equation (Olli et al. 2002):

$$
\begin{gathered}
\text { Daily loss rate }\left(\% \mathrm{~d}^{-1}\right)= \\
\text { Sedimentation rate } \times 100 / C_{\text {int }}
\end{gathered}
$$

where the sedimentation rate is from Eq. (1) and $C_{\text {int }}$ is the integrated concentration of the variable considered $\left(\mathrm{mg} \mathrm{m}^{-2}\right)$ in the depth strata above the sediment trap depth.

Retention (\%) was estimated for primary production and faecal pellets based on the equation from Riser et al. (2002):

$$
\begin{gathered}
\text { Retention }(\%)= \\
\left(P_{\text {int }}-\text { Sedimentation rate }\right) \times 100 / P_{\text {int }}
\end{gathered}
$$

where $P_{\text {int }}$ is the integrated total primary production or FPC production in the upper $50 \mathrm{~m}$ of the water column, $P_{\text {int }}$ - sedimentation rate is the absolute retention rate $\left(\mathrm{mg} \mathrm{m} \mathrm{m}^{-2} \mathrm{~d}^{-1}\right)$, and sedimentation rate is for POC or FPC measured at $50 \mathrm{~m}$ (see Eq. 1).

Zooplankton. The zooplankton distribution was sampled using a submersible pump (900 $1 \mathrm{~min}^{-1}$, HOMAH500, DIFRES-design) equipped with a flowmeter (Hydrobios), conical net (50 $\mu \mathrm{m}$ mesh size), and a nonfiltering cod-end. Samples were collected in 5 depth strata $(0-15,15-35,35-50,50-100$ and 100-200 m), corresponding to water column and sediment trap sampling depths. The samples were immediately preserved in buffered formalin ( $2 \%$ final concentration) for later analyses. Subsamples were taken using a sample-splitter, and the number of animals and their stages were recorded. The biomass values of the different animals were calculated based on measurements of their length in the different depth strata. In the present study, focus will be on the 4 upper sampling strata corresponding to the sediment trap depths. Further details on zooplankton distribution and ecology from this study can be found in Thor et al. (2005).

Faecal pellet production experiments. The faecal pellet production rates of the 3 most important copepod species, Calanus finmarchicus, C. glacialis and C. hyperboreus, were measured in the laboratory. Copepods were collected using a modified WP-2 net (45 $\mu \mathrm{m}$ mesh size) towed at low speed at the depth of the fluorescence maximum. On deck, the cod-end was gently diluted in surface water in a 1001 thermobox.

The experiments were conducted using a fecatron, constructed from an acrylic inner-tube with a $400 \mu \mathrm{m}$ mesh false bottom lowered into a 51 container filled with water from the fluorescence maximum depth. The fecatron was designed to eliminate grazing on produced faecal pellets (coprophagy) by allowing the faecal pellets to sink through the mesh out of the innertube, out of reach from the experiment animals. For each species-specific experiment, 20 Calanus finmarchicus, 20 C. glacialis or 10 C. hyperboreus females were incubated in a fecatron. Prior to the experiment the copepods were acclimatized in the fecatron filled with water from the fluorescence maximum depth and kept in a cold room $\left(\sim 0^{\circ} \mathrm{C}\right)$ for $2 \mathrm{~h}$. The copepods were then incubated under the same conditions for 2 to $6 \mathrm{~h}$, starting from the time when the inner-tube with the copepods was transferred from the acclimatization container to the incubation container, filled with the same type of water. The short incubation period (2 to $6 \mathrm{~h}$ ) was chosen to minimize changes in food concentration during the experiments due to sedimentation and grazing, which potentially could affect the faecal pellet production over time. At the end of the incubation period, the animals were removed, and faecal pellets were counted and measured.

Specific faecal pellet production rates (SPP, $\mu \mathrm{g} C \mu \mathrm{g}$ $\mathrm{C}^{-1} \mathrm{~d}^{-1}$ ) were calculated using the following equation:

$$
\operatorname{SPP}\left(\mu \mathrm{g} \mathrm{C} \mu \mathrm{g} \mathrm{C}^{-1} \mathrm{~d}^{-1}\right)=\mathrm{FPC}_{\text {prod }} /\left(C_{\mathrm{fem}} \times T_{\text {exp }}\right)
$$

where $\mathrm{FPC}_{\text {prod }}$ is the FPC ( $\mu \mathrm{g} \mathrm{C}$ ) produced during the experiment, $C_{\text {fem }}$ is the biomass $(\mu \mathrm{g}$ C) of the females based on length measurements of the in situ females and $T_{\text {exp }}$ is the duration (d) of the experiment.

Faecal pellet production experiments were performed with females only. However, since grazing rates (Hansen et al. 1997) and presumably faecal pellet production rate 
scales with the size of copepods, the specific female faecal pellet production rates (SPP) obtained from the experiments were scaled to match the average size of the species in the in situ population in order to calculate in situ faecal pellet production rates, according to the following equation (Hansen et al. 1997):

$$
\log \mathrm{SPP}=\log \mathrm{a}-0.23 \times \log V
$$

where SPP is the specific female faecal pellet production ( $\mu \mathrm{g} \mathrm{C} \mu \mathrm{g} \mathrm{C}^{-1} \mathrm{~d}^{-1}$ ), a is a constant and $V$ is the copepod female volume during the experiment $\left(\mu \mathrm{m}^{3}\right.$ cope$\left.\operatorname{pod}^{-1}\right)$.

In situ SPP were calculated for copepodite stages (CI-CVI) of the 3 Calanus species, using the specific a-values obtained from the regressions from each experiment. For nauplii of the 3 Calanus species and copepodites (CI-CVI) of the other copepod species in the water column, the a-values from C. finmarchicus, the smallest of the 3 examined Calanus species, were used. In the next sections, $\mathrm{SPP}_{\text {in situ }}$ refers to specific faecal pellet production estimates for the in situ community, i.e. estimated as described above, while SPP refers to specific faecal pellet production rates from the incubation experiments. By multiplying the $\mathrm{SPP}_{\text {in situ }}$ with the in situ copepod biomass an estimate of faecal pellet production by the copepod community was obtained.

The community faecal pellet production was used to estimate the grazing rate on phytoplankton assuming an assimilation efficiency of $60 \%$ (Conover 1966). Subsequently, daily loss rates $\left(\% \mathrm{~d}^{-1}\right)$ of suspended phytoplankton due to grazing were estimated using Eq. (3), but substituting the sedimentation rate for the grazing rate.

\section{RESULTS}

\section{Water column}

The water column was stratified during the entire sampling period. A characteristic feature was a cold water lens, with temperatures below $0.5^{\circ} \mathrm{C}$, located between the warmer surface and bottom water. The thickness of this lens decreased from $50 \mathrm{~m}$ to $0 \mathrm{~m}$ during the investigation (Fig. 2A). In general, the pelagic community was distributed according to the water column structure, with the highest abundance and biomass in association with the cold water lens. Results presented are average values $\pm \mathrm{SE}$, unless otherwise stated.

$\mathrm{Chl}$ a concentrations were low in the surface layer above the pycnocline ( 0 to $15 \mathrm{~m}$ ), averaging $0.9 \pm$ $0.2 \mathrm{mg} \mathrm{m}^{-3}$ ( $\left.\mathrm{n}=54\right)$ during the investigation (Fig. 2B). The intermediate layer (15 to $50 \mathrm{~m}$ ), where maximum chl a biomasses were observed, revealed strongly de- clining chl a concentrations during the first 3 sampling days and a slower decline thereafter. The highest chl a concentration, $31.2 \pm 1.0 \mathrm{mg} \mathrm{m}^{-3}(\mathrm{n}=3)$, was observed at $25 \mathrm{~m}$ on June 1 . The seasonal decrease resulted in a daily maximum chl a concentration of $2.1 \pm 0.05 \mathrm{mg} \mathrm{m}^{-3}$ $(\mathrm{n}=3)$ at $35 \mathrm{~m}$ on June 23 (end of sampling period). The thickness of the layer with chl a concentrations
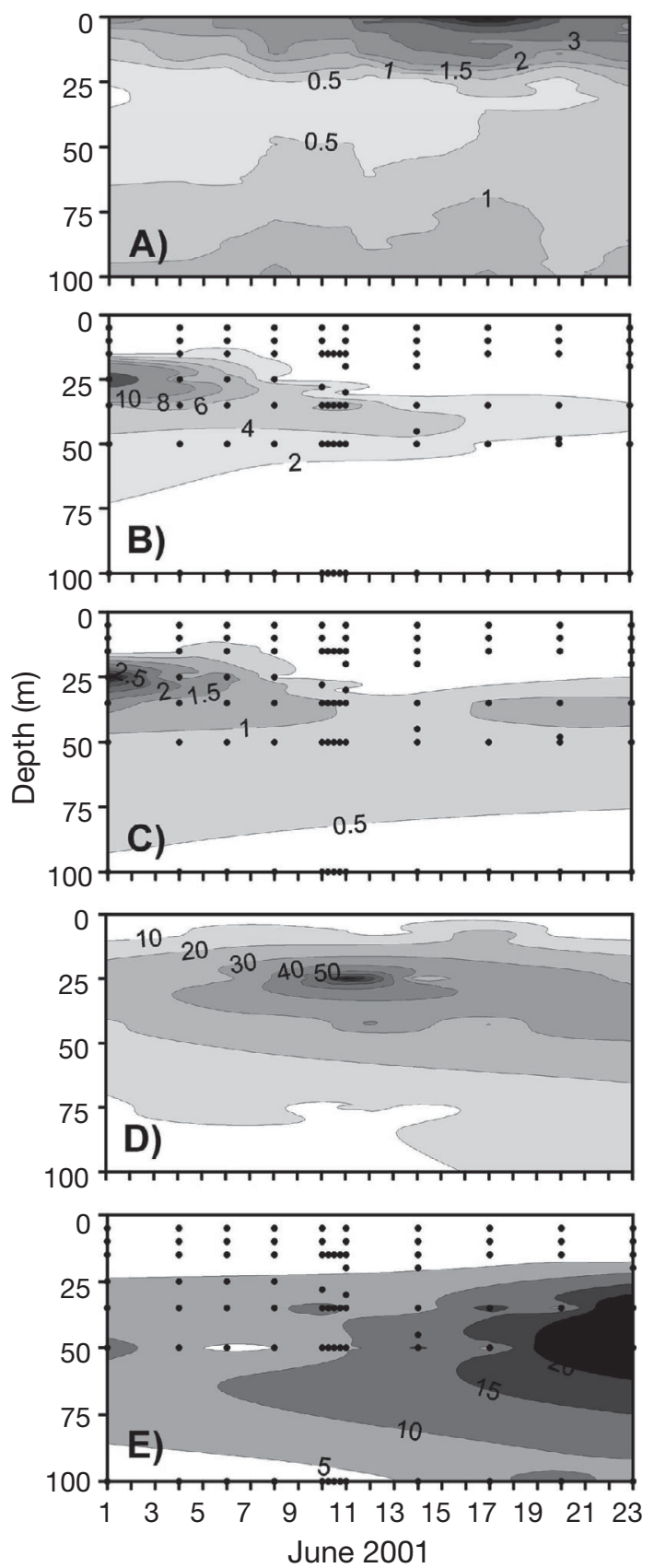

Fig. 2. Isolines of (A) temperature $\left({ }^{\circ} \mathrm{C}\right)$, (B) suspended chl a concentrations $\left(\mathrm{mg} \mathrm{m}^{-3}\right)$, (C) suspended phaeopigment concentrations $\left(\mathrm{mg} \mathrm{m}^{-3}\right)$, (D) carbon biomass of Calanus spp., copepodites and nauplii (mg C m ${ }^{-3}$ ) and (E) suspended faecal pellet carbon concentrations $\left(\mathrm{mg} \mathrm{C} \mathrm{m}^{-3}\right.$ ), in the top $100 \mathrm{~m}$. Points: sampling depths 
$>2 \mathrm{mg} \mathrm{m}^{-3}$ decreased from more than $35 \mathrm{~m}$ on June 1 to less than $15 \mathrm{~m}$ towards the end of the investigation, in parallel with the decreasing thickness of the cold water lens. On the first sampling day, June 1, the integrated phytoplankton biomass was $18 \mathrm{~g} \mathrm{C} \mathrm{m}^{-2}$ in the upper $50 \mathrm{~m}$; this value was reduced by more than $50 \%$ by June 6 (Fig. 2B). The depth of the euphotic zone (depth of $1 \%$ light penetration) remained stable throughout the investigation (averaging $46.5 \pm 3.4 \mathrm{~m}, \mathrm{n}=6$ ) .

POC and chl $a$ in the water column revealed a strong linearity according to the following equation (regression line not shown):

$$
\begin{gathered}
\mathrm{POC}=42.8 \pm 1.6 \times \mathrm{chl} a+165.1 \pm 9.0 \\
\left(\mathrm{r}^{2}=0.94, \mathrm{n}=36, \mathrm{p}<0.001\right)
\end{gathered}
$$

measured just below the euphotic zone $(6.4 \pm 0.9$ at $50 \mathrm{~m}$ ) or at $100 \mathrm{~m}$ (2-tailed $t$-test, p > 0.1) (Table 1).

The 3 large calanoid copepod species, Calanus finmarchicus, C. glacialis and C. hyperboreus, dominated the zooplankton community, averaging $88 \pm 2 \%(n=9)$ of the copepod carbon biomass ( 0 to $50 \mathrm{~m}$ ) during the investigation. The only other important genus was Metridia, with a biomass contribution of $6 \pm 2 \%$ (n = 9). Other copepod genera, such as Oithona, Pseudocalanus and Oncaea, were also found during the study. However, they represented only a minor percentage of the copepod biomass (Fig. 3). For further details on the copepod species composition see Thor et al. 2005.

The slope of the regression line was used for converting chl a measurements into PPC in the water column and sediment trap samples.

Phaeo concentrations in the surface layer (0 to $15 \mathrm{~m}$ ) remained low, averaging $0.2 \pm 0.05 \mathrm{mg} \mathrm{m}^{-3}(\mathrm{n}=54)$, during the investigation (Fig. 2C). In the intermediate layer, a pattern similar to that of chl a was observed for phaeo, with the highest concentration of $4.6 \pm 0.1 \mathrm{mg} \mathrm{m}^{-3}$ ( $\mathrm{n}=3$ ) measured at $25 \mathrm{~m}$ on the first sampling day (June 1), and a strong decline during the first 3 sampling days. Thereafter, a more modest decline was observed until June 14, followed by a slight increase during the last 3 sampling days resulting in a daily maximum phaeo concentration of $1.1 \pm 0.03 \mathrm{mg} \mathrm{m}^{-3}(\mathrm{n}=3)$ at $35 \mathrm{~m}$ on June 23 (Fig. 2C).

No significant difference in the POC: PON ratio of the suspended material was observed throughout the euphotic zone $(5,15,35 \mathrm{~m}$ and fluorescence maximum) (2-tailed $t$-test, $\mathrm{p}>0.1$ ), with an average POC:PON ratio of $8.1 \pm 0.4$ for the entire euphotic zone (depths $\leq 35 \mathrm{~m}$, Table 1 ). The POC:PON ratios in the euphotic zone were not significantly different from the ratios
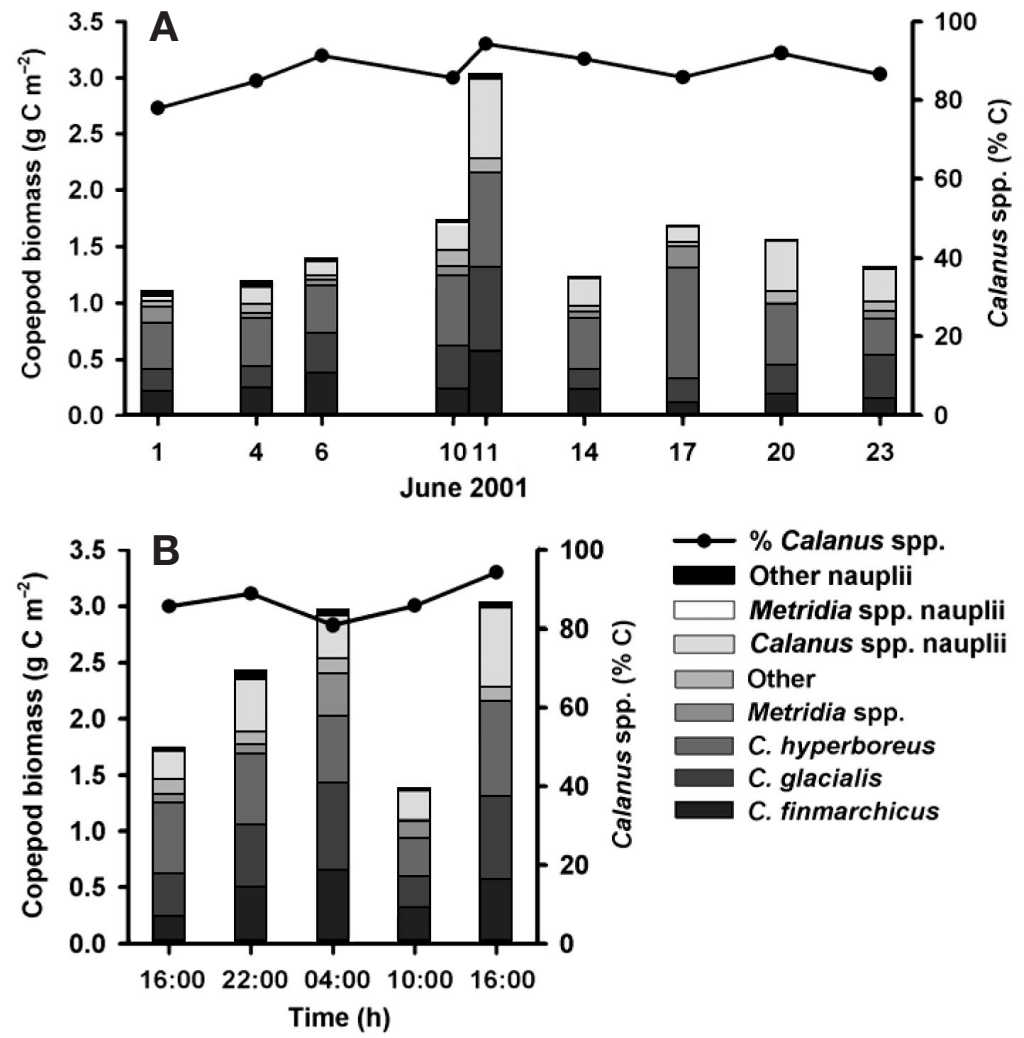

Fig. 3. Integrated carbon biomass of dominant copepod species and stages in top $50 \mathrm{~m}$ during (A) seasonal sampling, and (B) diurnal study, on June 10 to 11. Solid lines: carbon contribution of Calanus spp. to total copepod biomass

Table 1. Concentrations, sedimentation rates and ratios of particulate organic carbon and nitrogen (POC and PON) for suspended and sedimenting material in and below the euphotic zone. Sedimentation rates were estimated using Eq. (1). Data are averages \pm SE. Parentheses: number of data points

\begin{tabular}{|rcccccccc|}
\hline \multirow{2}{*}{$\begin{array}{c}\text { Depth } \\
(\mathrm{m})\end{array}$} & \multicolumn{2}{c}{ Suspended $\left(\mathrm{mg} \mathrm{m}^{-3}\right)$} & \multicolumn{3}{c}{ Sediment traps $\left(\mathrm{mg} \mathrm{m}^{-2} \mathrm{~d}^{-1}\right)$} & \multicolumn{3}{c|}{ POC:PON ratio } \\
\hline$\leq 35$ & POC & PON & POC & PON & Suspended & $\mathrm{r}^{2}$ & Sediment traps & $\mathrm{r}^{2}$ \\
\hline 50 & $212.9 \pm 26.7(32)$ & $34.1 \pm 3.0(32)$ & $640.6 \pm 57.7(32)$ & $74.5 \pm 5.8(32)$ & $8.1 \pm 0.4(32)$ & 0.91 & $8.3 \pm 0.6(32)$ & 0.86 \\
100 & $150.6 \pm 27.7(14)$ & $11.0 \pm 2.7(14)$ & $599.3 \pm 39.0(16)$ & $71.6 \pm 5.0(16)$ & $8.6 \pm 1.2(14)$ & 0.85 & $7.7 \pm 1.1(16)$ & 0.78 \\
\hline
\end{tabular}


A strong increase in copepod biomass was observed from June 10 to 11 , from $1.7 \mathrm{~g} \mathrm{C} \mathrm{m}^{-2}$ to $3.0 \mathrm{~g} \mathrm{C} \mathrm{m}^{-2}$ (0 to $50 \mathrm{~m})$, respectively. The maximum biomass of Calanus spp. was found in the intermediate layer (15 to $50 \mathrm{~m}$ ), associated with the maximum chl a layer (Fig. 2D). The daily maximum biomass of Calanus spp. recorded in the 15 to $35 \mathrm{~m}$ strata increased during the first half of the investigation, from $25 \mathrm{mg} \mathrm{C} \mathrm{m}^{-3}$ on June 1 to $90 \mathrm{mg}$ $\mathrm{C} \mathrm{m}^{-3}$ on June 11. Thereafter, the daily maximum Calanus spp. biomasses remained stable at approximately $34 \mathrm{mg} \mathrm{C} \mathrm{m}{ }^{-3}$ during the rest of the sampling period. A downward progression of this maximum Calanus spp. biomass layer, from the 15 to $35 \mathrm{~m}$ to the 35 to $50 \mathrm{~m}$ strata, was observed during the 2 last sampling days in parallel with the deepening of the chl $a$ maximum. The integrated copepod biomass in the upper $50 \mathrm{~m}$ ranged between 1.1 and $3.0 \mathrm{~g} \mathrm{C} \mathrm{m}^{-2}$ (averaging $1.6 \pm 0.2 \mathrm{~g} \mathrm{C} \mathrm{m}^{-2}, \mathrm{n}=9$ ) during the investigation (Fig. 3A).

The diurnal study did not suggest any diurnal copepod migration patterns in the upper $50 \mathrm{~m}$ (Fig. 3B). However, the copepod biomass continuously increased during the diurnal study, even though this trend was blurred by a significant decrease during the 10:00 $\mathrm{h}$
(June 11) sampling. Further details on the copepod community can be found in Thor et al. (2005).

FPC concentrations in the water column remained relatively stable until June 14, after which they increased to the highest measured concentration of $27 \mathrm{mg}$ $\mathrm{C} \mathrm{m}^{-3}$ at $50 \mathrm{~m}$ on June 20 (Fig. 2E). There was no change in the depth strata of the daily maximum FPC concentration during the investigation; only a slight widening of this layer was observed in the second half of the investigation. Average FPC concentrations paralleled the depth distribution of the copepods and were highest at 35 and $50 \mathrm{~m}$, with average values of $12.1 \pm 2.9$ and $13.0 \pm 3.0 \mathrm{mg} \mathrm{C} \mathrm{m}^{-3}(\mathrm{n}=9)$, respectively (Table 2). However, there was a temporal delay between the highest Calanus biomass (June 11) and the highest FPC concentrations (June 20), as the latter occurred later during the sampling period (Fig. 2D,E).

The median size of faecal pellets was significantly smaller in the water column than in the sediment traps at all depths except $100 \mathrm{~m}$ (Mann-Whitney $U$-test, $\mathrm{p}<$ 0.01). This reflects the relatively higher abundance of smaller faecal pellets in the water column (Fig. 4). In the sediment traps, the average and median faecal pellet volumes generally decreased with depth (Table 3 ).

Table 2. Suspended concentrations of POC and POC fractions (phytoplankton based POC [PPC], faecal pellet based POC [FPC] and amorphous detritus) at sediment trap depths, and the FPC part of suspended POC. Data are averages \pm SE. Parentheses: number of data points

\begin{tabular}{|c|c|c|c|c|c|}
\hline \multirow{2}{*}{$\begin{array}{l}\text { Depth } \\
\text { (m) }\end{array}$} & \multicolumn{5}{|c|}{ Suspended POC concentration $\left(\mathrm{mg} \mathrm{m}^{-3}\right.$ ) } \\
\hline & POC & PPC & FPC & Amorphous detritus & FPC part of POC (\%) \\
\hline 15 & $267.3 \pm 31.7(8)$ & $57.2 \pm 18.0(9)$ & $2.3 \pm 0.5(9)$ & $202.4 \pm 14.4(8)$ & $0.9 \pm 0.2(8)$ \\
\hline 35 & $369.3 \pm 36.2(7)$ & $201.3 \pm 31.8$ & $12.1 \pm 2.9$ & $158.3 \pm 20.0(7)$ & $4.3 \pm 1.3(7)$ \\
\hline 50 & $212.4 \pm 19.0$ & $100.2 \pm 17.8$ & $13.0 \pm 3.0$ & $110.5 \pm 15.3$ & $6.3 \pm 1.7(8)$ \\
\hline 100 & $150.6 \pm 27.7(7)$ & $17.2 \pm 1.8(9)$ & $4.9 \pm 1.4$ & $127.7 \pm 26.5(7)$ & $3.9 \pm 1.3(7)$ \\
\hline
\end{tabular}

Table 3. Faecal pellet concentrations and dimensions (width, length and volume) in water column and sediment traps. Sedimentation rates were estimated using Eq. (1). Data are averages \pm SE, except for median and maximum volumes. Parentheses: number of samples or data points

\begin{tabular}{|c|c|c|c|c|c|c|}
\hline \multirow{2}{*}{$\begin{array}{l}\text { Depth } \\
\text { (m) }\end{array}$} & \multirow[t]{2}{*}{ Concentration $^{\mathrm{a}}$} & \multirow{2}{*}{$\begin{array}{l}\text { Width } \\
(\mu \mathrm{m})\end{array}$} & \multirow{2}{*}{$\begin{array}{l}\text { Length } \\
(\mu \mathrm{m})\end{array}$} & \multicolumn{3}{|c|}{ Volume $\left(10^{6} \mu \mathrm{m}^{3}\right)$} \\
\hline & & & & Average & Median & Maximum \\
\hline \multicolumn{7}{|c|}{ Water column } \\
\hline 15 & $8.6 \pm 2.2(9)$ & $99 \pm 3(170)$ & $439 \pm 21(170)$ & $4.4 \pm 0.5(170)$ & 2.2 & 59 \\
\hline 35 & $32.1 \pm 6.3(9)$ & $99 \pm 3(322)$ & $508 \pm 22(322)$ & $6.5 \pm 0.7(322)$ & 1.9 & 109 \\
\hline 50 & $30.2 \pm 5.7(9)$ & $116 \pm 3(384)$ & $506 \pm 18(384)$ & $7.8 \pm 0.7(384)$ & 3.1 & 123 \\
\hline 100 & $12.7 \pm 2.6(9)$ & $124 \pm 4(218)$ & $425 \pm 17(218)$ & $7.3 \pm 0.8(218)$ & 3.4 & 81 \\
\hline \multicolumn{7}{|c|}{ Sediment trap } \\
\hline 15 & $43.2 \pm 13.4$ & $112 \pm 4(105)$ & $601 \pm 40(105)$ & $8.1 \pm 1.0(105)$ & 5.2 & 70 \\
\hline 35 & $327.2 \pm 55.0$ & $111 \pm 1(847)$ & $548 \pm 12(847)$ & $6.3 \pm 0.2(847)$ & 4.3 & 61 \\
\hline 50 & $479.6 \pm 114.4$ & $111 \pm 1(1168)$ & $544 \pm 9(1168)$ & $6.6 \pm 0.2(1168)$ & 4.1 & 92 \\
\hline 100 & $502.3 \pm 134.7$ & $115 \pm 1(1230)$ & $456 \pm 8(1230)$ & $5.7 \pm 0.2(1230)$ & 3.9 & 88 \\
\hline
\end{tabular}


Concomitantly, faecal pellet lengths decreased with depth, whereas faecal pellet width remained constant. In the water column, faecal pellet width increased with depth (50 and $100 \mathrm{~m}$ were significantly higher than 15 and $35 \mathrm{~m}$ ), but faecal pellet length did not vary significantly with depth.

PPC made up, on average, $41.2 \pm 5.6 \%(n=8)$ of the integrated POC in the upper $50 \mathrm{~m}$ of the water column during the sampling period. FPC constituted, on aver-
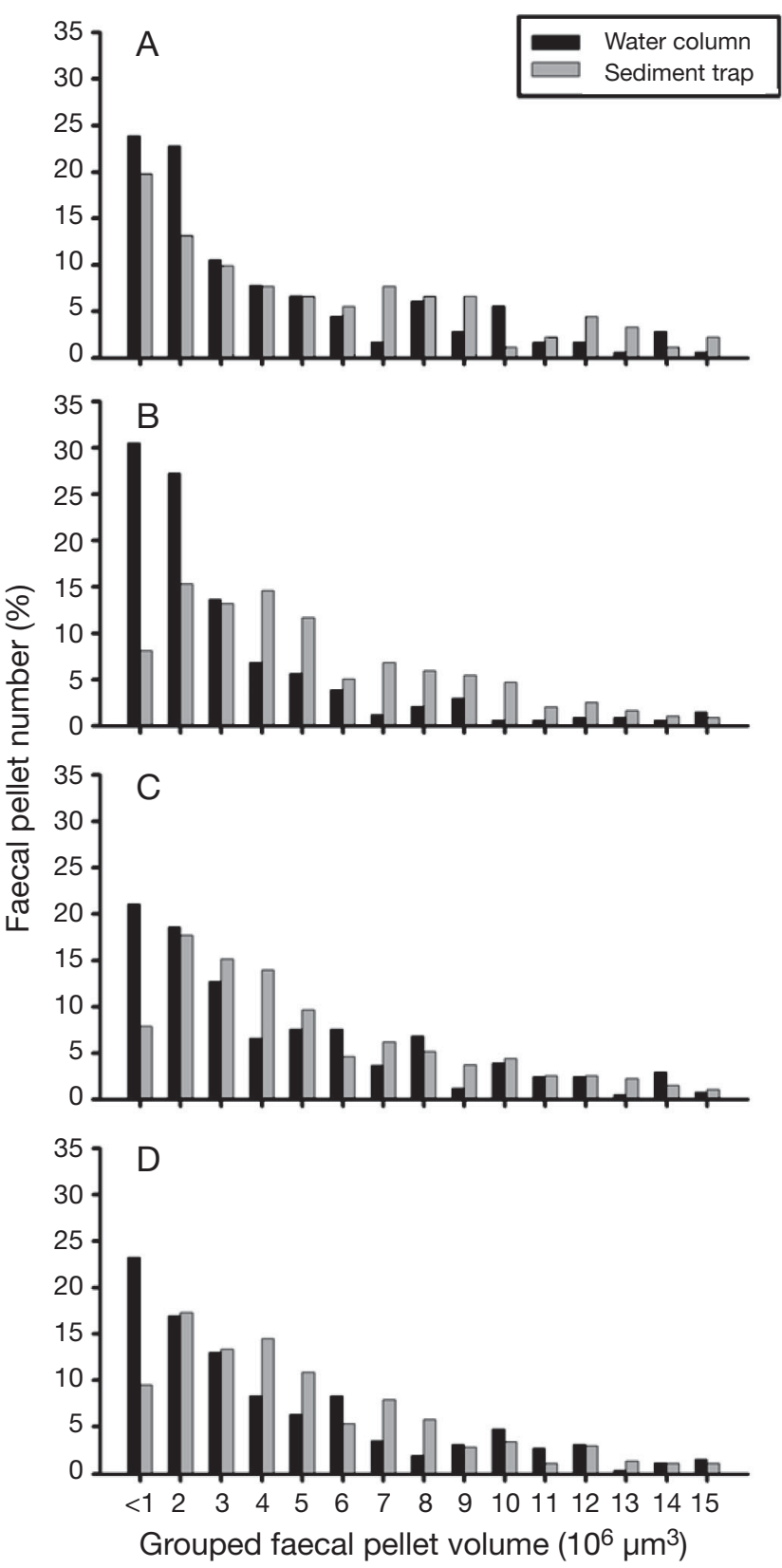

Fig. 4. Size distribution of individual faecal pellet volumes in water column and sediment trap samples at (A) 15, (B) 35 , (C) 50, and (D) $100 \mathrm{~m}$ for the entire study. See Table 3 for average, mean and maximum sizes age, $2.8 \pm 0.8 \%(n=8)$ of the integrated POC in the upper $50 \mathrm{~m}$. Amorphous detritus made up most of the suspended POC, averaging $8.3 \pm 0.5 \mathrm{~g} \mathrm{C} \mathrm{m}^{-2}(\mathrm{n}=8)$ and making up $55.9 \pm 5.1 \%$ of the integrated POC in the upper $50 \mathrm{~m}$.

\section{Faecal pellet production experiments}

Faecal pellet production was measured for all 3 Calanus species throughout the investigation. The numbers of faecal pellets produced during the experiments did not differ significantly (ANOVA, 1-way, $\mathrm{df}=2,46, \mathrm{p}>0.1$ ) between species, and were found to be $53 \pm 5,48 \pm 4$ and $53 \pm 12$ faecal pellets female ${ }^{-1} \mathrm{~d}^{-1}$ for C. finmarchicus, C. glacialis and C. hyperboreus, respectively (Table 4 ). Average faecal pellet volumes were similar for $C$. finmarchicus and C. glacialis (averaging $7.3 \pm 0.2 \times 10^{6}{\mu \mathrm{m}^{3}}^{3} \mathrm{n}=1944$, and $7.3 \pm 0.3 \times$ $10^{6} \mu^{3}, \mathrm{n}=1065$, respectively), while pellets produced by $C$. hyperboreus were larger (averaging $14.0 \pm 0.8 \times$ $10^{6} \mathrm{\mu m}^{3}, \mathrm{n}=697$ ) (Table 4). The faecal pellets from the production experiments were generally larger than the faecal pellets measured in the water column and sediment trap samples (median values in Tables $3 \& 4$; Figs. 4 \& 5). Faecal pellet volumes also varied between water column and sediment trap samples. The dominant faecal pellet volumes in the water column were between $<1 \times 10^{6}$ and $2 \times 10^{6}{\mu \mathrm{m}^{3}}^{3}$, whereas they were between $2 \times 10^{6}$ and $4 \times 10^{6} \mu^{3}$ in sediment traps deployed below the surface layer (below $15 \mathrm{~m}$ ) (Fig. 4).

The average SPP from the incubation experiments were $0.17 \pm 0.02,0.05 \pm 0.005$ and $0.08 \pm 0.02 \mu \mathrm{g} \mathrm{C} \mu \mathrm{g}$ $\mathrm{C}^{-1} \mathrm{~d}^{-1}$ for Calanus finmarchicus, C. glacialis and $C$. hyperboreus, respectively (Table 4 ). The SPP of $C$. finmarchicus differed significantly from that of the 2 other species (2-tailed $t$-test, $\mathrm{p}<0.01)$, while $C$. glacialis and C. hyperboreus showed no significant difference in their SPP (2-tailed $t$-test, $\mathrm{p}>0.1$ ). SPP of both $C$. finmarchicus and C. glacialis were positively correlated with the availability of potential food in the water column, assumed to be the biomass of large phytoplankton cells represented by $>10 \mu \mathrm{m}$ chl $a$ at the depth of the fluorescence maximum (Fig. 6A,B). The data in Fig. 6A and B were fitted to a hyperbolic regression, as follows:

$$
\mathrm{SPP}=\left(\mathrm{SPP}_{\max } \times(\operatorname{chl} a) /\left(K_{\mathrm{m}}+(\operatorname{chl} a)\right)\right.
$$

where $\mathrm{SPP}_{\max }$ is the maximum specific faecal pellet production and $K_{\mathrm{m}}$ is the half saturation constant, i.e. the chl a concentration $(>10 \mu \mathrm{m})$ at which $\mathrm{SPP}=$ $\mathrm{SPP}_{\max } / 2$.

$\mathrm{SPP}_{\max }$ was found to be $0.23 \pm 0.03$ and $0.06 \pm 0.01 \mu \mathrm{g}$ $\mathrm{C} \mu \mathrm{g} \mathrm{C}^{-1} \mathrm{~d}^{-1}$ for Calanus finmarchicus and C. glacialis, respectively. C. hyperboreus did not reveal any sig- 
Table 4. Calanus spp. Faecal pellet production rates and dimensions of pellets from faecal pellet production experiments. Data are averages \pm SE. Parentheses: number of data points

\begin{tabular}{|c|c|c|c|c|c|c|c|}
\hline \multirow{3}{*}{ Species } & \multirow{3}{*}{\multicolumn{2}{|c|}{$\begin{array}{c}\text { Faecal pellet production rate } \\
\begin{array}{cc}\left(\text { No. animal }^{-1} \mathrm{~d}^{-1}\right) & (\mu \mathrm{g} \mathrm{C} \\
\left.\mu \mathrm{g} \mathrm{C}^{-1} \mathrm{~d}^{-1}\right)\end{array}\end{array}$}} & \multirow{3}{*}{$\begin{array}{c}\text { Width } \\
(\mu \mathrm{m})\end{array}$} & \multicolumn{4}{|c|}{ Faecal pellet dimensions } \\
\hline & & & & \multirow{2}{*}{$\begin{array}{l}\text { Length } \\
(\mu \mathrm{m})\end{array}$} & \multicolumn{3}{|c|}{ Volume $\left(10^{6} \mu \mathrm{m}^{3}\right)$} \\
\hline & & & & & Average & Median & Maximum \\
\hline C. finmarchicus & $53 \pm 5(16)$ & $0.17 \pm 0.02(16)$ & $104 \pm 1(1944)$ & $773 \pm 8(1944)$ & $7.3 \pm 0.2(1944)$ & 8.6 & 140 \\
\hline C. glacialis & $48 \pm 4(15)$ & $0.05 \pm 0.005(15)$ & $106 \pm 1(1065)$ & $702 \pm 12(1065)$ & $7.3 \pm 0.3(1065)$ & 4.8 & 105 \\
\hline C. hyperboreus & $53 \pm 12(12)$ & $0.08 \pm 0.02(12)$ & $132 \pm 2(697)$ & $784 \pm 21(697)$ & $14.0 \pm 0.8(697) 0$ & 7.7 & 182 \\
\hline
\end{tabular}

nificant SPP saturation pattern with increasing chl a (>10 $\mu \mathrm{m})$ concentrations (Fig. 6C).

The estimated in situ specific faecal pellet production $\left(\mathrm{SPP}_{\text {in situ }}\right)$ varied from $0.08 \pm 0.01 \mu \mathrm{g} \mathrm{C} \mu \mathrm{g} \mathrm{C}^{-1} \mathrm{~d}^{-1}$ for Calanus glacialis to $0.55 \pm 0.06 \mu \mathrm{g} \mathrm{C} \mu \mathrm{g} \mathrm{C}^{-1} \mathrm{~d}^{-1}$ for the Calanus nauplii (Table 5).

\section{Sinking and grazing losses (seasonal study)}

Pronounced temporal and vertical differences were observed in the sedimentation of particulate organic material. Highest sedimentation rates were observed before June 10, when high suspended chl a concentrations were present in the subsurface layer. Sedimentation rates of POC rapidly declined during the first 3 sampling days and did not show any clear temporal trend afterwards (Fig. 7). Average POC sedimentation rates during the investigation were not significantly different between depths (ANOVA, 1-way, log transformed data, $\mathrm{df}=3,32, \mathrm{p}>0.1$ ), ranging from $599 \pm 39$ ( $\mathrm{n}=16)$ at $100 \mathrm{~m}$ to $649 \pm 109 \mathrm{mg} \mathrm{C} \mathrm{m}^{-2} \mathrm{~d}^{-1}(\mathrm{n}=16)$ at $15 \mathrm{~m}$ (Fig. 7). The POC:PON ratios of the material collected in the sediment traps did not differ between the
Table 5. Calanus spp. and others. Estimated in situ specific faecal pellet production rates $\left(\mathrm{SPP}_{\text {in situ }}\right)$. See 'Faecal pellet production experiments' in 'Materials and methods' section for explanation regarding the calculations. Data are averages \pm SE. Parentheses: number of data points

\begin{tabular}{|lcc|}
\hline Species & Stage & $\begin{array}{c}\mathrm{SPP}_{\text {in situ }} \\
\left(\mu \mathrm{C} \mu \mathrm{g} \mathrm{C}^{-1} \mathrm{~d}^{-1}\right)\end{array}$ \\
\hline C. finmarchicus & Average (CI - CVI) & $0.23 \pm 0.02(9)$ \\
C. glacialis & Average (CI - CVI) & $0.08 \pm 0.01(9)$ \\
C. hyperboreus & Average (CI - CVI) & $0.14 \pm 0.03(9)$ \\
Calanus spp. & Nauplii & $0.55 \pm 0.06(9)$ \\
Others & Average (CI - CVI) & $0.43 \pm 0.05(9)$ \\
\hline
\end{tabular}

4 depths (2-tailed $t$-test, $\mathrm{p}>0.1$ ) (Table 1). Maximum PPC sedimentation rates were measured before June 10, with the highest sedimentation rate of $533 \mathrm{mg}$ $\mathrm{C} \mathrm{m}^{-2} \mathrm{~d}^{-1}$ observed at $50 \mathrm{~m}$ on June 4 (Fig. 7C). PPC sedimentation averaged $455 \pm 83 \mathrm{mg} \mathrm{C} \mathrm{m}^{-2} \mathrm{~d}^{-1}$ at $50 \mathrm{~m}$ $(\mathrm{n}=3)$ before June 10 and $142 \pm 9 \mathrm{mg} \mathrm{C} \mathrm{m}^{-2} \mathrm{~d}^{-1}(\mathrm{n}=6)$ after June 10. Average PPC sedimentation was significantly higher at 35 and $50 \mathrm{~m}$ compared to the 2 other sediment trap depths (paired $t$-test, $\mathrm{p}<0.01$ ), with values of $206 \pm 49$ and $243 \pm 58 \mathrm{mg} \mathrm{C} \mathrm{m}^{-2} \mathrm{~d}^{-1}(\mathrm{n}=18)$ at 35 and $50 \mathrm{~m}$, respectively. These PPC sedimentations represented $30 \pm 5 \%$ and $36 \pm 6 \%$ of the total POC at 35 and $50 \mathrm{~m}$, respectively (Fig. 7). Linear regression between chl $a$ and POC in the sediment traps followed this equation (regression line not shown):

$$
\begin{aligned}
& \mathrm{POC}=42.7 \pm 6.1 \times \mathrm{chl} a+454.4 \pm 28.9 \\
& \left(\mathrm{r}^{2}=0.52, \mathrm{n}=36, \mathrm{p}<0.001\right)
\end{aligned}
$$

Average sedimentation of FPC significantly increased with depth during the investigation (2-tailed $t$-test, $\mathrm{p}<0.01$ ), from $22 \pm 12(\mathrm{n}=8)$ at $15 \mathrm{~m}$ to $190 \pm 40 \mathrm{mg}$ $\mathrm{C} \mathrm{m}^{-2} \mathrm{~d}^{-1}(\mathrm{n}=9)$ at $50 \mathrm{~m}$, and remained at a similar level at $100 \mathrm{~m}$ (Fig. 7). The percent contribution of FPC to the sedimenting POC also increased with depth (2-tailed $t$-test, $\mathrm{p}<0.01$ ), from an average of $2.6 \pm 1.0 \%(n=8)$ at $15 \mathrm{~m}$ to $28.8 \pm 4.8 \%$

Fig. 5. Calanus spp. Size distribution of individual faecal pellet volumes from the specific faecal pellet production experiments. See Table 4 for average, mean and maximum sizes 



Fig. 6. Calanus spp. Specific faecal pellet production rates (SPP, $\mu \mathrm{g} \mathrm{C} \mu \mathrm{g} \mathrm{C}^{-1} \mathrm{~d}^{-1}$ ) as a function of chl $a>10 \mu \mathrm{m}$ concentrations $\left(\mathrm{mg} \mathrm{m}^{-3}\right)$ at depth of maximum fluorescence for (A) C. finmarchicus, (B) C. glacialis, and (C) C. hyperboreus. SPP rates are estimated using Eq. (5). Solid lines represent the fit to a hyperbolic regression: $C$. finmarchicus: $\mathrm{SPP}=0.23 \pm$ $0.03 \times \mathrm{chl} a /(0.39 \pm 0.18+\mathrm{chl} a), \mathrm{r}^{2}=0.46, \mathrm{n}=17, \mathrm{p}<0.01$; C. glacialis: $\mathrm{SPP}=0.06 \pm 0.01 \times \mathrm{chl} a /(0.34 \pm 0.21+\mathrm{chl} a)$, $\mathrm{r}^{2}=0.31, \mathrm{n}=17, \mathrm{p}<0.05$

$(\mathrm{n}=9)$ and $28.4 \pm 6.5 \%(\mathrm{n}=9)$ at 50 and $100 \mathrm{~m}$, respectively. FPC sedimentation was significantly correlated with that of phaeo, according to the following linear regression (regression line not shown):

$$
\begin{gathered}
\mathrm{FPC}=24.7 \pm 3.1 \times \text { phaeo }+22.9 \pm 13.6 \\
\left(\mathrm{r}^{2}=0.68, \mathrm{n}=32, \mathrm{p}<0.001\right)
\end{gathered}
$$

Amorphous detritus constituted the main component of the POC sedimentation at $15 \mathrm{~m}$, averaging $537 \pm$ $69 \mathrm{mg} \mathrm{C} \mathrm{m}^{-2} \mathrm{~d}^{-1}(\mathrm{n}=9$ ) (equal to $87 \pm 4 \%$ of the POC sedimentation) (Fig. 7). The amorphous detritus fraction of POC sedimentation was somewhat lower at the
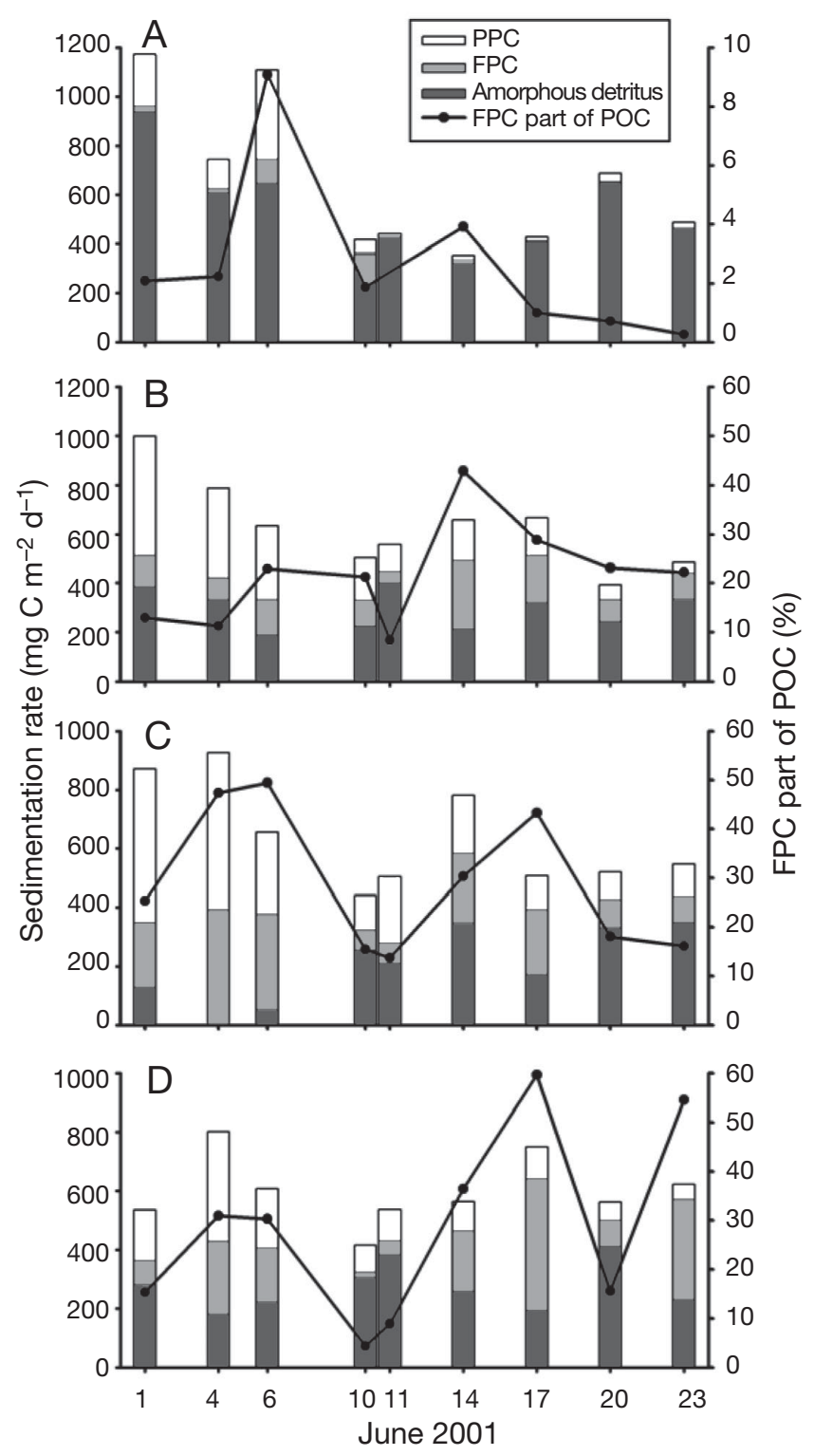

Fig. 7. Seasonal trends in sedimentation of total particulate organic carbon (POC) and the phytoplankton (PPC), faecal pellet (FPC) and amorphous detritus fractions of POC sedimentation (mg C m${ }^{-2} \mathrm{~d}^{-1}$ ) at (A) 15, (B) 35, (C) 50, and (D) $100 \mathrm{~m}$. Sedimentation rates were estimated using Eq. (1). Solid lines: FPC part of POC sedimentation. Values from June 10 and 11 are from beginning and end of diurnal study

other depths, averaging $294 \pm 26 \mathrm{mg} \mathrm{C} \mathrm{m}^{-2} \mathrm{~d}^{-1}(\mathrm{n}=9)$ (equal to $49 \pm 5 \%$ of the total POC) at $35 \mathrm{~m}, 195 \pm$ $50 \mathrm{mg} \mathrm{C} \mathrm{m}^{-2} \mathrm{~d}^{-1}(\mathrm{n}=9)$ (equal to $35 \pm 9 \%$ of the POC) at $50 \mathrm{~m}$, and $275 \pm 27 \mathrm{mg} \mathrm{C} \mathrm{m}^{-2} \mathrm{~d}^{-1}(\mathrm{n}=9)$ (equal to $49 \pm 7 \%$ of the total POC) at $100 \mathrm{~m}$. Thus, the 3 POC components (PPC, FPC and amorphous detritus) constituted a similar percentage of the POC sedimentation just below the euphotic zone $(50 \mathrm{~m})$. 
Average sinking velocities of PPC were $<1.5 \mathrm{~m} \mathrm{~d}^{-1}$ at 15 and $35 \mathrm{~m}$, and increased with depth, up to $8.1 \pm$ $1.9 \mathrm{~m} \mathrm{~d}^{-1}(\mathrm{n}=9)$ at $100 \mathrm{~m}$ (Table 6). Average sinking velocities for FPC also increased with depth, ranging from $10 \pm 5 \mathrm{~m} \mathrm{~d}^{-1}(\mathrm{n}=8)$ at $15 \mathrm{~m}$ to $66 \pm 24 \mathrm{~m} \mathrm{~d}^{-1}(\mathrm{n}=9)$ at $100 \mathrm{~m}$. Sinking velocities of amorphous detritus did not show any trend with depth and showed only slight variation, ranging between $2.1 \pm 0.5(\mathrm{n}=7)$ and $2.8 \pm$ $0.4 \mathrm{~m} \mathrm{~d}^{-1}(\mathrm{n}=7)$ at 50 and $15 \mathrm{~m}$, respectively. Average sinking velocities of POC increased with depths below $15 \mathrm{~m}$, reaching $4.8 \pm 0.6 \mathrm{~m} \mathrm{~d}^{-1}(\mathrm{n}=7)$ at $100 \mathrm{~m}$.

The daily loss rate of suspended PPC due to sedimentation remained relatively constant throughout the investigation averaging $3.8 \pm 0.5 \% \mathrm{~d}^{-1}$ at $50 \mathrm{~m}$ (Fig. 8). The grazing impact, on the other hand, was similar to the daily loss due to sedimentation on June $1\left(3 \% \mathrm{~d}^{-1}\right.$ at $50 \mathrm{~m}$ ), after that it became increasingly more important. After June 10 the daily loss rate due to grazing was 4 to 10 times higher than the daily loss rate due to sedimentation. The daily loss rate due to grazing averaged $17.7 \pm 3.6 \% \mathrm{~d}^{-1}$ at $50 \mathrm{~m}$ during the entire sampling period (Fig. 8). The daily loss rate of FPC peaked on June 4 and 6 , with values of 144 and $147 \% \mathrm{~d}^{-1}$ at $50 \mathrm{~m}$, respectively, followed by a smaller peak on June 14 with $93 \% \mathrm{~d}^{-1}$ at $50 \mathrm{~m}$ (Fig. 8). The daily loss rate of FPC averaged $65.5 \pm 18.5 \% \mathrm{~d}^{-1}$ at $50 \mathrm{~m}$ during the investigation. The daily loss rates of POC ranged from $17.5 \pm 0.7$ to $2.8 \pm 0.1 \% \mathrm{~d}^{-1}$, and the daily loss rates of PON ranged from $18.3 \pm 0.7$ to $3.2 \pm 0.1 \% \mathrm{~d}^{-1}$, at 15 and $100 \mathrm{~m}$, respectively (data not shown). The seasonally averaged daily loss rate of POC and PON did not differ significantly within each depth interval (paired $t$-test, $\mathrm{p}>0.1$ ).

The estimated PPC retention in the upper $50 \mathrm{~m}$ revealed a high negative value $(-93 \%)$ on the first sampling day (Fig. 9). During the rest of the sampling period PPC retention demonstrated a general declining trend, with the highest retention value of $83 \%$ estimated on June 6 . This declining trend was, however, to some extend blurred by the negative estimates on June 11 and 14 (Fig. 9). According to the FPC retention estimates (see Eq. 4), more FPC sedimented at $50 \mathrm{~m}$

Table 6. Sinking velocities of POC and POC fractions (PPC, FPC and amorphous detritus) at sediment trap depths. Sinking velocities were estimated using Eq. (2). Data are averages \pm SE. Parentheses: number of data points

\begin{tabular}{|ccccc|}
\hline \multirow{2}{*}{$\begin{array}{l}\text { Depth } \\
(\mathrm{m})\end{array}$} & \multicolumn{5}{c}{\begin{tabular}{c} 
Sinking velocities $\left(\mathrm{m} \mathrm{d}^{-1}\right)$ \\
\cline { 3 - 5 }
\end{tabular}} & POC & PPC & FPC & $\begin{array}{c}\text { Amorphous } \\
\text { detritus }\end{array}$ \\
\hline 15 & & & & \\
35 & $1.7 \pm 0.2(7)$ & $1.1 \pm 0.2(9)$ & $15 \pm 4(9)$ & $2.1 \pm 0.4(7)$ \\
50 & $2.9 \pm 0.2(8)$ & $3.2 \pm 1.2(9)$ & $25 \pm 9(9)$ & $2.1 \pm 0.5(7)$ \\
100 & $4.8 \pm 0.6(7)$ & $8.1 \pm 1.9(9)$ & $66 \pm 24(9)$ & $2.4 \pm 0.5(7)$ \\
\hline
\end{tabular}

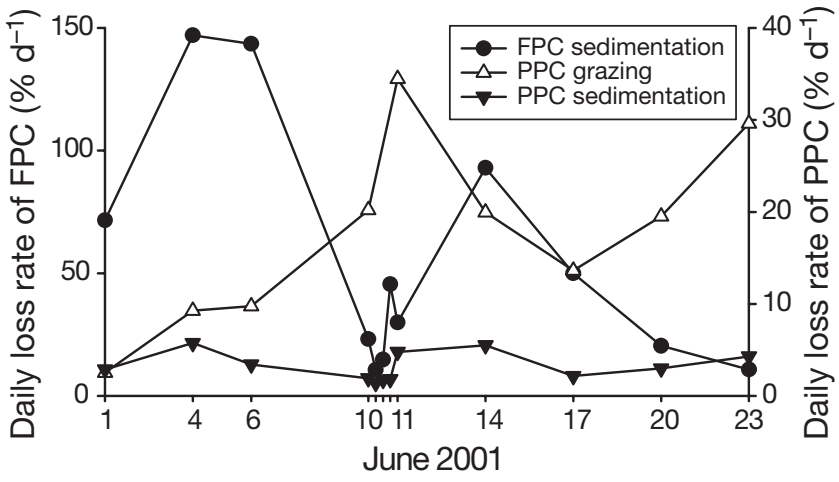

Fig. 8. Daily loss rate of FPC due to sedimentation during sampling period, for 0 to $50 \mathrm{~m}$ depth strata, and of PPC due to grazing and sedimentation. Daily loss rates were estimated using Eq. (3)

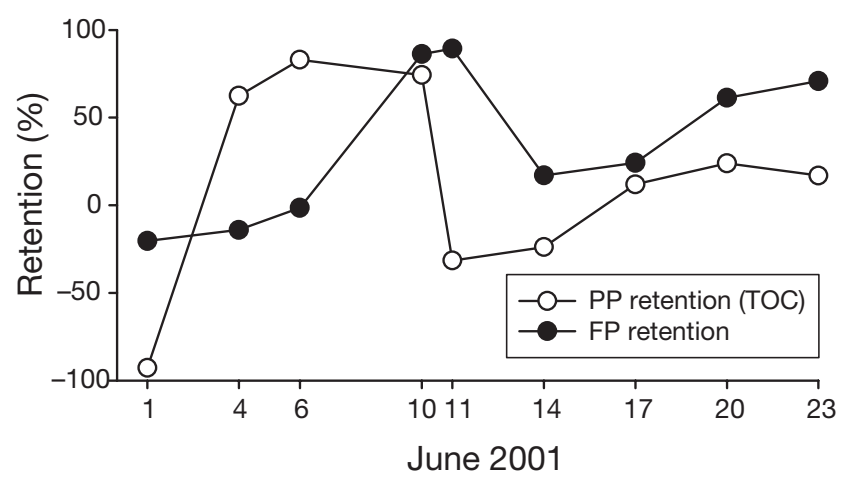

Fig. 9. Retention of primary production (PP) as total organic carbon (TOC) and faecal pellets (FP) in upper $50 \mathrm{~m}$. Retention was estimated using Eq. (4). PP data originates from T. G. Nielsen et al. unpubl.

than appeared to be produced in the upper $50 \mathrm{~m}$ until June 6 (Fig. 9). During the entire sampling period, $34.7 \pm 14.3 \%$ of the faecal pellet production was retained in the upper $50 \mathrm{~m}$. Absolute FPC retention (mg C $\mathrm{m}^{-2} \mathrm{~d}^{-1}$ ) in the upper $50 \mathrm{~m}$ was significantly correlated with the biomass of Oithona spp. and Oncaea spp. (absolute retention $=30 \mathrm{~d}^{-1} \times$ biomass $-327, \mathrm{r}^{2}=0.79, \mathrm{p}=$ 0.001 ) and total copepods (absolute retention $=0.40 \mathrm{~d}^{-1}$ $\times$ biomass $-362, r^{2}=0.62, p=0.01$ ).

\section{Sinking losses (Diurnal study)}

The diurnal study showed less variation in POC sedimentation rates (coefficient of variation $[\mathrm{CV}]=22.0 \%$ for all depths), compared to the seasonal study (CV = $31.2 \%$ for all depths, Figs. $7 \& 10$ ). During the diurnal study, amorphous detritus was the major component of the POC sedimentation at $15 \mathrm{~m}(92 \pm 2 \%, \mathrm{n}=5)$, while at 35, 50 and $100 \mathrm{~m}$ PPC made up a substantial fraction 
$(26 \pm 3,29 \pm 4$ and $20 \pm 1 \%, n=5$, respectively) of the sinking POC (Fig. 10). The average FPC fraction increased from $2.5 \pm 1.8 \%(\mathrm{n}=4)$ at $15 \mathrm{~m}$ to $14.3 \pm$ $3.0 \%(\mathrm{n}=5)$ at $35 \mathrm{~m}$ and decreased slightly to $13.4 \pm$ $1.3 \%$ and $11.0 \pm 2.0 \%(\mathrm{n}=5)$ at $50 \mathrm{~m}$ and $100 \mathrm{~m}$, respectively.
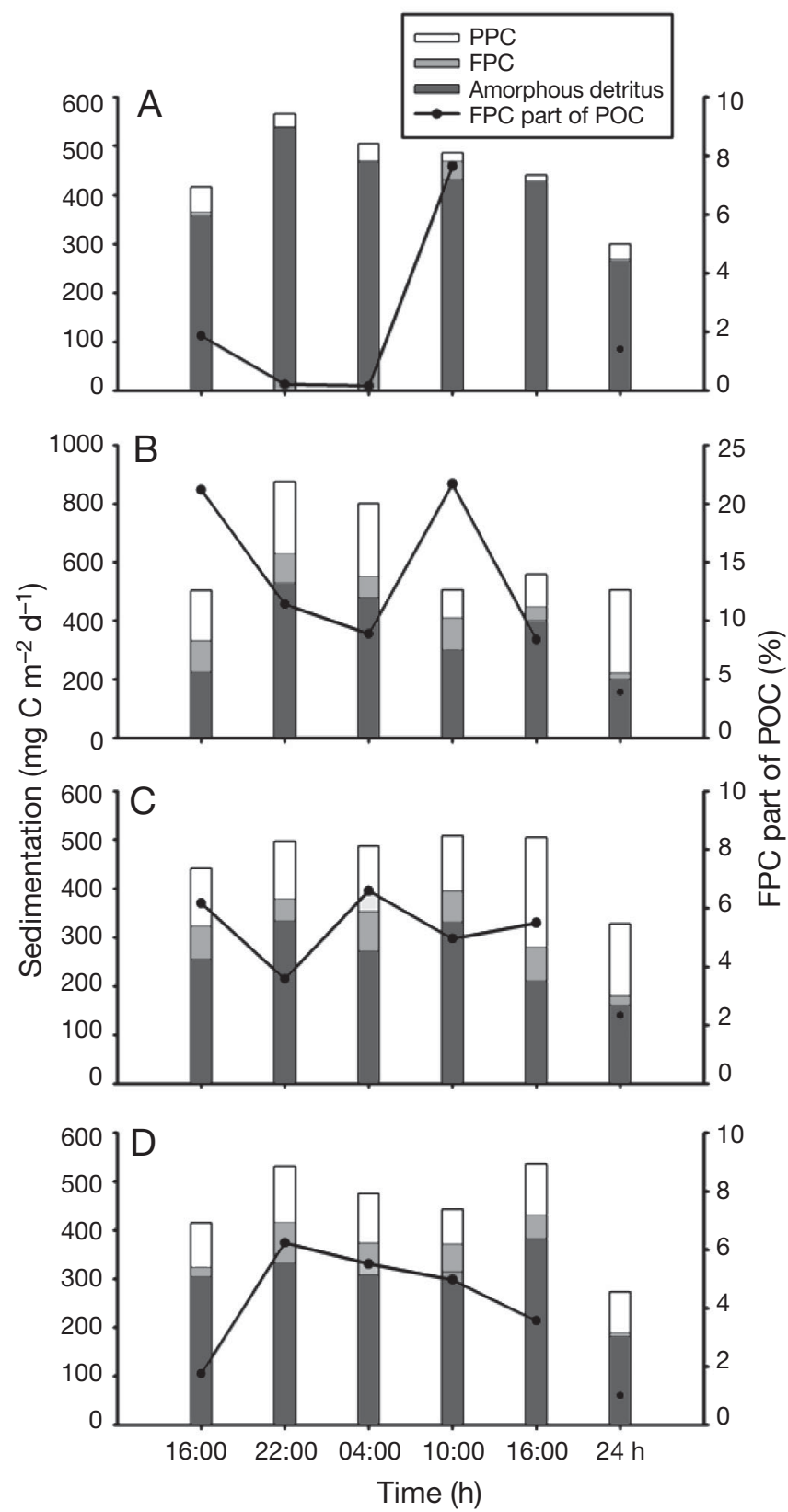

Fig. 10. Diurnal trends in sedimentation of total POC and PPC, FPC and amorphous detritus fractions of POC sedimentation (mg C m ${ }^{-2} \mathrm{~d}^{-1}$ ), during $6 \mathrm{~h}$ deployments (times on $x$-axis: sediment trap recovery; $24 \mathrm{~h}$ : separate $24 \mathrm{~h}$ deployment array) on 10 and 11 June at (A) 15, (B) 35, (C) 50, and (D) $100 \mathrm{~m}$. Sedimentation rates were estimated using

Eq. (1). Solid lines: FPC part of the POC sedimentation
The total POC, FPC and amorphous detritus sedimentation rates during the diurnal study were significantly lower for all depths during the $24 \mathrm{~h}$ deployment compared to the $6 \mathrm{~h}$ deployments (paired $t$-test, $\mathrm{p}<$ 0.05), while PPC sedimentation did not show any significant difference between the 6 and $24 \mathrm{~h}$ deployments (paired t-test, $\mathrm{p}>0.05$ ) (Fig. 10).

\section{DISCUSSION}

\section{The spring bloom}

The break-up of the sea ice typically set the stage for the initiation of the pelagic spring primary production in seasonally ice covered environments, but ultimately the maximum biomass attained by phytoplankton depends on the nutrient supply. The duration of the spring bloom, however, is also influenced by the meteorological conditions, as wind mixing can delay stabilization of the water column. In 2001, the sea ice in the Disko Bay broke up on April 10 and drifted within the bay, before completely retreating on April 29 (N. Nielsen pers. comm.). Consequently, the open water period started one month prior to the beginning of the present investigation. The vertical distribution of phytoplankton together with nitrate depletion in the surface layer (Nielsen et al. unpubl.), indicate a transition from a bloom to a postbloom situation at the start of the present investigation. This is similar to the conditions observed in 1996 and 1997 when the spring bloom in the Disko Bay area reached its maximum about 1 wk after the ice break-up (Levinsen et al. 2000a). On the west coast of Greenland, the spring bloom generally takes place over a few weeks, until it terminates due to nutrient depletion in the euphotic zone (Andersen 1981, Nielsen \& Hansen 1995, Poulsen $\&$ Reuss 2002).

Nitrogen has been shown to be the limiting factor for the spring bloom in the Disko Bay area (Andersen 1981, Nielsen \& Hansen 1995, 1999, Nielsen et al. unpubl.). Thus, the ability of the pelagic system to recycle nitrogen within the euphotic zone is the determining factor for (regenerated) primary production during the nutrient limited summer conditions (Harrison \& Cota 1991). Comparing the POC:PON ratios of the suspended particulate material in the euphotic zone to that of the particulate material sedimenting below the euphotic zone gives an indication of the ability of the system to retain nitrogen in relation to carbon. In addition, the POC:PON ratio of particulate material sinking at different depths can provide evidence of differential remineralization of carbon and nitrogen. The fact that there were no significant differences between the POC:PON ratios for the suspended 
material in the euphotic zone and that of the particulate material sedimenting at $50 \mathrm{~m}$ indicates that the suspended organic material was sedimenting unchanged (Table 1). The similar POC:PON ratios at the different sediment trap depths also indicate that there was no preferential remineralization of carbon versus nitrogen as the material sank to depth. The similar daily loss rates of carbon and nitrogen within each sampling depth interval further support these results, showing that the pelagic system did not retain nitrogen more efficiently than carbon at the termination of the spring bloom.

The POC:PON ratio of the sedimenting particulate material was similar to what was found in sinking material composed primarily of nitrate deficient diatoms from NE Greenland (Daly et al. 1999). However, this does not account for the high sedimentation of faecal pellets, which should increase the POC:PON ratio of the sedimenting particulate material (Olesen \& Lundsgaard 1995, Daly et al. 1999).

The fact that there were no significant difference in the regression slopes for POC versus chl $a$ in the water column and sedimenting material (2-tailed $t$-test, $\mathrm{p}>$ 0.1 , also corroborates that the carbon content of the sedimenting phytoplankton did not change in comparison to that of the suspended biomass. The difference between the y-intercepts (165.1 and $454.4 \mathrm{mg} \mathrm{C} \mathrm{m}^{-2} \mathrm{~d}^{-1}$ for suspended and sedimenting biomass, respectively) indicates high sedimentation of additional POC which was not phytoplankton related i.e. faecal pellets and amorphous detritus. Indeed, these contributors constituted a large part of the vertical export of carbon, representing between 36 and $82 \%$ of the sinking POC at $50 \mathrm{~m}$.

\section{Termination of the spring bloom}

The rapid decrease of phytoplankton biomass during the first sampling days was likely the result of the high phytoplankton sedimentation rates at that time (Fig. 7), combined with zooplankton grazing (Fig. 8). The daily loss rate estimates of phytoplankton due to sedimentation remained seemingly low during the first sampling days, despite the high phytoplankton sedimentation rates (Fig. 8). The high chl a concentration measured at


explained the low daily loss rate due to sedimentation on this day. However, the high negative phytoplankton retention (-93\%) on June 1 (Fig. 9), shows that almost twice as much PPC was sedimenting (at $50 \mathrm{~m}$ ) compared to what was being produced (at 0 to $50 \mathrm{~m}$ ). This negative retention of phytoplankton observed during the first sampling day was consistent with the termination of the spring bloom, most likely due to nutrient limitation, and subsequent high export through sedimentation.

The high sedimentation at the beginning of the sampling period could be caused by a high degree of aggregation due to high cell concentrations (Kiørboe \& Hansen 1993, Kiørboe et al. 1994, Hansen et al. 1995). The observed increase in PPC sinking velocity with depth (Table 6) supports the potential formation of aggregates during sinking. Other biological processes, such as nutrient limitation of algae, or physical factors, such as decreased mixing with depth, could also lead to increased sinking velocities with depth. However, our results show a clear increase in sinking velocities for PPC and FPC, while sinking velocities of amorphous detritus do not change with depth (Table 6). These results therefore rule out potential effects from physical factors, which would likely influence all particles in a similar manner, and they also rule out nutrient limitation which would only affect PPC sinking velocities. Consequently, aggregation appears to be a likely hypothesis for the depth related increase in PPC and FPC sinking velocities. Many phytoplankton species possess a degree of stickiness or produce sticky transparent exopolymeric particles, which further induce or enhance aggregation (Kiørboe \& Hansen 1993, Hansen et al. 1995, Passow 1991). This pattern of termination and subsequent loss of nutrient-depleted spring bloom has been observed in many temperate (Lignell et al. 1993, Kiørboe et al. 1994, Olesen \& Lundsgaard 1995, Tiselius \& Kuylenstierna 1996, Heiskanen et al. 1998) and arctic areas (Bauerfeind et al. 1997, Wassmann et al. 1999). The sedimentation rates measured during the present study are comparable to the high rates reported in the Barents Sea during May 1993 (409-1090 mg POC m ${ }^{-2} \mathrm{~d}^{-1}$ at 20-200 m, Andreassen \& Wassmann 1998) and the North Water polynya, Baffin Bay during 1998 (155-1104 mg POC m $\mathrm{m}^{-2} \mathrm{~d}^{-1}$ at $50 \mathrm{~m}$, Michel et al. 2002).

The use of both 6 and $24 \mathrm{~h}$ sediment trap deployments made it possible to compare short deployments (6 h) with deployments carried out during a complete diurnal period $(24 \mathrm{~h})$. No significant differences were observed in the sedimentation rates for the 5 individual $6 \mathrm{~h}$ deployments during the diurnal study, which supports the approach of using one $6 \mathrm{~h}$ deployment to estimate daily sedimentation rates during the present investigation. Sedimentation of the phytoplankton fraction was similar when comparing the 6 and $24 \mathrm{~h}$ deployments. However, the amorphous detritus and FPC fractions were found to be significantly lower in the $24 \mathrm{~h}$ deployments compared to the $6 \mathrm{~h}$ deployments. We are uncertain as to the cause of this discrepancy. One possible explanation could be that these fractions are subject to degradation loss in the sediment traps. If the degradation of the amorphous detri- 
tus and FPC fractions is biologically induced, the relatively short timescale ( $24 \mathrm{~h}$ ) makes it unlikely that bacterial activity alone would be the cause. Although visual inspection of the sediment trap content only revealed swimmers on a few occasions, it is possible that grazing on faecal pellets and other organic material did occur. It is also possible that the $6 \mathrm{~h}$ deployment 'over-trapped' faecal pellets and amorphous detritus, in which case some of our results could be overestimated.

\section{Calanus grazing and faecal pellet production}

The copepod community in Disko Bay was dominated by 3 species, Calanus finmarchicus, C. glacialis and $C$. hyperboreus (Fig. 3). This Calanus dominance has previously been observed in the Disko Bay area during the spring of 1992 (Nielsen \& Hansen 1995), spring/summer of 1996 and 1997 (Madsen et al. 2001), and in other Arctic areas as well (Tande \& Båmstedt 1985, Hirche 1991, Hirche \& Mumm 1992, Ashjian et al. 1997). Calanus is therefore considered to be a key genus in Arctic marine pelagic food webs, although more complex food web structures including smaller copepod species and the microbial loop are now documented for Arctic areas as well (Taniguchi 1984, Rivkin et al. 1996, Levinsen \& Nielsen 2002, Møller et al. 2006, Thor et al. 2005).

Calanus spp. start their ascent to the surface layer just prior to, or in association with, the sea-ice breakup and the initiation of the spring bloom (Madsen et al. 2001). Copepod biomass in the euphotic zone peaked in the beginning of June in both 1996 and 1997 (Madsen et al. 2001), which combined with the sea-ice break-up during the last week of April in both years, is similar to the observations during the present investigation. The stable copepod biomass observed in the water column (Fig. 3) supports the assumption that the present investigation was conducted during a stable maximum in Calanus activity. Spatial and temporal studies on Calanus feeding biology have documented shifting diets (Ohman \& Runge 1994, Levinsen et al. 2000b, Sato et al. 2002), which makes it relevant to classify this genus as omnivorous, instead of strictly herbivorous. However, the prevailing feeding strategy during the present investigation would most likely be herbivorous, due to the abundance of phytoplankton compared with heterotrophic prey (Nielsen et al. unpubl.). The relationship between faecal pellet production and phytoplankton (Fig. 6) supports the importance of phytoplankton as a major food source for Calanus during the spring of 2001. Moreover, the strong correlation between the sedimentation of FPC and phaeo indicates a mainly herbivorous feeding, since degradation of chlorophyll is one of the main sources of phaeo (Welschmeyer \& Lorenzen 1985, Olli et al. 2002).

The number of faecal pellets produced did not vary significantly between species, but when the specific faecal pellet production was estimated, the differences between species became obvious (Table 4, Fig. 6). Calanus glacialis had the lowest specific faecal pellet production rates of the 3 species, despite variations in the rates observed for $C$. hyperboreus. Similar values and patterns of specific faecal pellet production rates were found, when the data of Daly (1997) and Rey et al. (1999) were recalculated to $0^{\circ} \mathrm{C}\left(\mathrm{Q}_{10}=2.8\right.$, Hansen et al. 1997). The biomass of single female copepods from the present study and a carbon conversion factor of $69.4 \mu \mathrm{g} \mathrm{C} \mathrm{mm}{ }^{-3}$ for the pellets (Riebesell et al. 1995) were used for the recalculation. The specific faecal pellet production rates estimated from this conversion were 0.02 to $0.06 \mu \mathrm{g} \mathrm{C} \mu \mathrm{g} \mathrm{C} \mathrm{C}^{-1} \mathrm{~d}^{-1}$ for $C$. glacialis and $0.09 \mu \mathrm{g} \mathrm{C} \mu \mathrm{g} \mathrm{C}^{-1} \mathrm{~d}^{-1}$ for C. hyperboreus, which were similar to the rates we measured for $C$. glacialis and $C$. hyperboreus (Table 4). However, estimates for the specific faecal pellet production rates of $C$. finmarchicus (0.04 to $0.06 \mu \mathrm{g} \mathrm{C} \mu \mathrm{g} \mathrm{C}^{-1} \mathrm{~d}^{-1}$ ) was found to be lower than the rates measured in our study.

The copepod community was able to graze a significant fraction of the phytoplankton standing stock (averaging $18 \% \mathrm{~d}^{-1}$ ), and demonstrated an increasing trend as the bloom declined (Fig. 8). In the post bloom period, the loss of phytoplankton through grazing was much higher than the loss through sedimentation.

\section{Loss of faecal pellets}

Sediment traps deployed just below the euphotic zone $(50 \mathrm{~m})$ showed that faecal pellets contributed, on average, $29 \%$ of the POC sedimentation (Fig. 7). This value is within the range reported for other Arctic ecosystems (Turner 2002). In the Norwegian Sea, during May and June, 7 to $90 \%$ of the POC sedimentation was attributable to faecal pellets (Bathmann et al.1987, Wassmann et al. 1999). In the Barents Sea near Spitsbergen, the FPC fraction ranged from 2 to $42 \%$ of the sedimenting POC during March and May (Riser et al. 2002). However, a large fraction of the faecal pellets was still being remineralized in the upper part of the water column during the present study (Fig. 9). On average, $35 \%$ of the faecal pellets produced during the sampling period were retained in the upper $50 \mathrm{~m}$ of the water column. In the Barents Sea, between 40 and $96 \%$ of the faecal pellet produced were retained in the surface layer (Riser et al. 2002), while in the Norwegian Sea approximately $99 \%$ of the standing stock of 
faecal pellets was recycled in the surface layer daily (Bathmann et al. 1987).

Microbial degradation alone would probably not be very effective in remineralizing the sinking faecal pellets, due to their high sinking velocity (Table 6). However, in other investigations, copepods (González and Smetacek 1994), Noctiluca scintillans (Kiørboe 2003) and pteropods (Jackson 1993) have all been shown to remove or break down faecal pellets. Among copepod species, Oithona spp. and Oncaea spp. have been shown to be associated with faecal pellets and other sinking aggregates (Gonzáles and Smetacek 1994, Metz 1998). These particular copepod species were found to be present during this investigation (Thor et al. 2005).

We found a significant positive correlation between absolute FPC retention and the biomass of Oithona spp. and Oncaea spp. in the upper $50 \mathrm{~m}$. However, the slope of the regression (i.e. $30 \mathrm{~d}^{-1}$ ) suggests that these 2 genera should be able to process 30 times their own body weight per day if the relation is causal, which is not likely. The total biomass of copepods also correlated significantly with the absolute FPC retention, with a linear regression slope of $0.4 \mathrm{~d}^{-1}$. Although the other copepod genera present are not generally considered to be associated with faecal pellets they can still graze upon them (Maar et al. 2004). Thus, it is possible that the total copepod community, and not just Oncaea and Oithona, played a role in the recycling of faecal pellets.

We found a larger percentage of small faecal pellets in the water column than in the sediment traps (Fig. 4), suggesting preferential sedimentation of larger faecal pellets. The dominant faecal pellet sizes in the sediment traps resembled that of faecal pellets produced by Calanus spp. (Figs. 4 \& 5). Thus, faecal pellet production by Calanus species was important for the sedimentation of particulate organic material because these species dominated the copepod biomass. Furthermore, since smaller faecal pellets appeared to remain in suspension, these would be prone to more efficient recycling. Our results therefore agree with the suggestion that most of the faecal pellets produced by small copepods will be degraded and remineralized within the euphotic zone (Viitasalo et al. 1999). Interestingly, some very large faecal pellets were found in the water column (Table 3). The presence of these large faecal pellets explains the fact that the average faecal pellet volume was similar in the traps and the water column (Table 3), despite the higher abundance of small faecal pellets in the water column. These large faecal pellets appeared to be lost or broken down before reaching the sediment traps, since none where found in the collected material (Table 3).

\section{CONCLUSION}

Calanus spp. dominated the zooplankton biomass during this study. Their grazing and the sedimentation of phytoplankton were equally important during the termination of the spring bloom. However, in the post bloom period, copepod grazing became more important in the removal of phytoplankton biomass from the euphotic zone. On the one hand, copepod faecal pellets were as important for the vertical export of carbon as the phytoplankton and amorphous detritus fractions. On the other hand, $35 \%$ of the copepod faecal pellet production was recycled in the euphotic zone, thus fuelling regenerated primary production. In addition to the recycling of faecal pellets, copepods also played an important role in retaining material in the euphotic zone through production of dissolved organic matter by sloppy feeding and leakage from faecal pellets (Møller et al. 2003). Nevertheless, the nitrogen retention efficiency of this post bloom community appeared to be low, as illustrated by (1) the comparable carbon/chl $a$ and carbon/nitrogen ratios of the suspended material and of the material collected in sediment traps, and (2) the consistency of the POC:PON ratio in the sedimenting material at various depths. The inefficiency of the system to retain the limiting nitrogen emphasizes the potential importance of the microbial retention of copepod mediated dissolved organic matter for preserving nutrients in the euphotic zone after the spring bloom, which will be discussed in a subsequent paper (T.G. Nielsen et al. unpubl.).

Acknowledgements. The present study was supported by the Nordic Arctic Research Program (Grant No. 50-031), by the Danish Natural Science Research Council (Grant No. 51-000415, Grant No. 9801391 and Grant No. 9700196) and the Nordic Academy for Advanced Study (NorFa, mobility stipendium No. 010031). The Swedish Polar Research Secretariat and the Broms Foundation provided support for P.T. and E.S. The Arctic station, University of Copenhagen, provided an excellent working platform in Qeqertarsuaq. F. Steffens, captain of RV 'Maja S', provided great technical support. In particular we thank B. Søborg for skilled technical assistance, and 4 anonymous reviewers for helpful comments on the manuscript.

\section{LITERATURE CITED}

Acuña JL, Deibel D, Morris CC (1996) Particle capture mechanism of the pelagic tunicate Oikopleura vanhoeffeni. Limnol Oceanogr 41:1800-1814

Andersen OGN (1981) The annual cycle of phytoplankton, primary production and hydrography in the Disko Bugt area, West Greenland. Medd Gronl 6:1-65

Andreassen IJ, Wassmann P (1998) Vertical flux of phytoplankton and particulate biogenic matter in the marginal ice zone of the Barents Sea in May 1993. Mar Ecol Prog Ser 170:1-14 
Ashjian C, Smith S, Bignami F, Hopkins T, Lane P (1997) Distribution of zooplankton in the Northeast Water Polynya during summer 1992. J Mar Syst 10:279-298

Bathmann UV, Noji TT, Voss M, Peinert R (1987) Copepod faecal pellets - abundance, sedimentation and content at a permanent station in the Norwegian Sea in May/June 1986. Mar Ecol Prog Ser 38:45-51

Bauerfeind E, Garrity C, Krumbholz M, Ramseier RO, Voss M (1997) Seasonal variability of sediment trap collections in the Northeast Water Polynya. 2. Biochemical and microscopic composition of sedimenting matter. J Mar Syst 10: 371-389

Buch E, Pedersen SA, Ribergaard MR (2004) Ecosystem variability in West Greenland waters. J Northwest Atl Fish Sci Vol. 34:13-28

Conover RJ (1966) Factors affecting the assimilation of organic matter by zooplankton and the question of superfluous feeding. Limnol Oceanogr 11:346-354

Daly KL (1997) Flux of particulate matter through copepods in the Northeast Water Polynya. J Mar Syst 10:319-342

Daly KL, Wallace DWR, Smith WO, Skoog A, Lara R, Gosselin M, Falck E, Yager PL (1999) Non-Redfield carbon and nitrogen cycling in the Arctic: effects of ecosystem structure and dynamics. J Geophys Res 104:3185-3199

González HE, Smetacek V (1994) The possible role of the cyclopoid copepod Oithona in retarding vertical flux of zooplankton faecal material. Mar Ecol Prog Ser 113: 233-246

Hansen JLS, Timm U, Kiørboe T (1995) Adaptive significance of phytoplankton stickiness with emphasis on the diatom Skeletonema costatum. Mar Biol 123:667-676

Hansen PJ, Bjørnsen PK, Hansen BW (1997) Zooplankton grazing and growth: scaling within the $2-2000 \mu \mathrm{m}$ body size range. Limnol Oceanogr 42(4):687-704

Harrison WG, Cota GF (1991) Primary production in polar waters-relation to nutrient availability. Polar Res 10: 87-104

Heiskanen AS, Haapala J, Gundersen K (1998) Sedimentation and pelagic retention of particulate $\mathrm{C}, \mathrm{N}$ and $\mathrm{P}$ in the coastal northern Baltic Sea. Estuar Coast Shelf Sci 46: $703-712$

Hirche HJ (1991) Distribution of dominant calanoid copepod species in the Greenland Sea during late fall. Polar Biol 11: 351-362

Hirche HJ (1996) The reproductive biology of the marine copepod, Calanus finmarchicus-a review. Ophelia 44: 111-128

Hirche HJ, Mumm N (1992) Distribution of dominant copepods in the Nansen Basin, Arctic Ocean, in summer. DeepSea Res 39:485-505

Jackson GA (1993) Flux feeding as a mechanism for zooplankton grazing and its implications for vertical particulate flux. Limnol Oceanogr 38(6):1328-1331

Jespersen AM, Christoffersen K (1987) Measurements of chlorophyll a from phytoplankton using ethanol as extraction solvent. Arch Hydrobiol 109:445-454

Kiørboe T (2003) High turnover rates of copepod faecal pellets due to Noctiluca scintillans grazing. Mar Ecol Prog Ser 258:181-188

Kiørboe T, Hansen JLS (1993) Phytoplankton aggregate formation: observations of patterns and mechanisms of cell sticking and the significance of exopolymeric material. J Plank Res 15:993-1018

Kiørboe T, Nielsen TG (1994) Regulation of zooplankton biomass and production in a temperate, coastal ecosystem. 2. Copepods. Limnol Oceanogr 39(3):493-507

Kiørboe T, Lundsgaard C, Olesen M, Hansen JLS (1994)
Aggregation and sedimentation processes during a spring phytoplankton bloom: a field experiment to test coagulation theory. J Mar Res 52:297-323

Kiørboe T, Hansen JLS, Alldredge AL, Jackson GA and 5 others (1996) Sedimentation of phytoplankton during a diatom bloom: rates and mechanisms. J Mar Res 54: 1123-1148

Knap A, Michaels A, Close A, Dusklow H, Dickson A (eds) (1996) Protocols for the Joint Global Ocean Flux Study (JGOFS) core measurements. JGOFS Report Nr. 19, Reprint of the IOC Manuals and Guides No. 29, UNESCO, Bergen

Levinsen H, Nielsen TG (2002) The trophic role of marine pelagic ciliates and heterotrophic dinoflagellates in arctic and temperate coastal ecosystems: a cross-latitude comparison. Limnol Oceanogr 47:427-439

Levinsen H, Nielsen TG, Hansen BW (2000a) Annual succession of marine pelagic protozoans in Disko Bay, West Greenland, with emphasis on winter dynamics. Mar Ecol Prog Ser 206:119-134

Levinsen H, Turner JT, Nielsen TG, Hansen BW (2000b) On the trophic coupling between protists and copepods in arctic marine ecosystems. Mar Ecol Prog Ser 204:65-77

Lignell R, Heiskanen AS, Kuosa H, Gundersen K, Kuuppoleinikki P, Pajuniemi R, Uitto A (1993) Fate of a phytoplankton spring bloom - sedimentation and carbon flow in the planktonic food web in the Northern Baltic. Mar Ecol Prog Ser 94:239-252

Maar M, Nielsen TG, Gooding S, Tönnesson K and 5 others (2004) Trophodynamic function of copepods, appendicularians and protozooplankton in the late summer zooplankton community in the Skagerrak. Mar Biol 144: 917-933

Madsen SD, Nielsen TG, Hansen BW (2001) Annual population development and production by Calanus finmarchicus, C. glacialis and C. hyperboreus in Disko Bay, western Greenland. Mar Biol 139:75-93

Metz C (1998) Feeding of Oncaea curvata (Poecilostomatoida, Copepoda). Mar Ecol Prog Ser 169:229-235

Michel C, Gosselin M, Nozais C (2002) Preferential sinking export of biogenic silica during the spring-summer in the North Water Polynya (northern Baffin Bay): temperature or biological control? J Geophys Res 107:1-14

Møller EF, Thor P, Nielsen TG (2003) Production of DOC by Calanus finmarchicus, C. glacialis and C. hyperboreus through sloppy feeding and leakage from faecal pellets. Mar Ecol Prog Ser 262:185-191

Møller EF, Nielsen TG, Richardson K (2006) The zooplankton community in the Greenland Sea: composition and role in carbon turnover. Deep-Sea Res I 53:76-93

Nielsen TG, Hansen BW (1995) Plankton community structure and carbon cycling on the western coast of Greenland during and after the sedimentation of a diatom bloom. Mar Ecol Prog Ser 125:239-257

Nielsen TG, Hansen BW (1999) Plankton community structure and carbon cycling on the western coast of Greenland during the stratified summer situation. I. Hydrography, phytoplankton and bacterioplankton. Aquat Microb Ecol 16:205-216

Ohman MD, Runge JA (1994) Sustained fecundity when phytoplankton resources are in short supply-omnivory by Calanus finmarchicus in the Gulf of St.-Lawrence. Limnol Ocanogr 39:21-36

Olesen M, Lundsgaard C (1995) Seasonal sedimentation of autochthonous material from the euphotic zone of a coastal system. Estuar Coast Shelf Sci 41:475-490

Olli K, Riser CW, Wassmann P, Ratkova T, Arashkevich E, 
Pasternak A (2002) Seasonal variation in vertical flux of biogenic matter in the marginal ice zone and the central Barents Sea. J Mar Syst 38:189-204

Passow U (1991) Species-specific sedimentation and sinking velocities of diatoms. Mar Biol 108:449-455

Pasternak A, Arashkevich E, Tande K, Falkenhaug T (2001) Seasonal changes in feeding, gonad development and lipid stores in Calanus finmarchicus and C. hyperboreus from Malangen, northern Norway. Mar Biol 138:1141-1152

Poulsen LK, Reuss N (2002) The plankton community on Sukkertop and Fylla Banks off West Greenland during a spring bloom and post-bloom period: hydrography, phytoplankton and protozooplankton. Ophelia 56:69-85

Rey C, Carlotti F, Tande K, Hygum BH (1999) Egg and faecal pellet production of Calanus finmarchicus females from controlled mesocosms and in situ populations: influence of age and feeding history. Mar Ecol Prog Ser 188:133-148

Riebesell U, Reigstad M, Wassmann P, Noji T, Passow U (1995) On the trophic fate of Phaeocystis pouchetii (Hariot). VI. Significance of Phaeocystis-derived mucus for vertical flux. Neth J Sea Res 33:193-203

Riser CW, Wassmann P, Olli K, Pasternak A, Arashkevich E (2002) Seasonal variation in production, retention and export of zooplankton faecal pellets in the marginal ice zone and central Barents Sea. J Mar Syst 38:175-188

Rivkin RB, Anderson MR, Lajzerowicz C (1996) Microbial processes in cold oceans. I. Relationship between temperature and bacterial growth rate. Aquat Microb Ecol 10: 243-254

Sato M, Sasaki H, Fukuchi M (2002) Stable isotopic compositions of overwintering copepods in the arctic and subarctic waters and implications to the feeding history. J Mar Syst 38:165-174

Strickland JDH, Parsons TR (1972) A practical handbook of sea-water analysis. Bull Fish Res Board Can 167:1-310

Editorial responsibility: Otto Kinne (Editor-in-Chief), Oldendorf/Luhe, Germany
Tande KS, Båmstedt U (1985) Grazing rates of the copepods Calanus glacialis and Calanus finmarchicus in Arctic waters of the Barents Sea. Mar Biol 87:251-258

Taniguchi A (1984) Microzooplankton biomass in the arctic and subarctic Pacific Ocean in summer. Mem Natl Inst Polar Res (Spec Issue) 32:63-76

Thor P, Nielsen TG, Tiselius $\mathrm{P}$, Juul-Pedersen T and 5 others (2005) Post spring bloom community structure of pelagic copepods in the Disko Bay, Western Greenland. J Plankton Res 27(4):341-356

Tiselius P, Kuylenstierna M (1996) Growth and decline of a diatom spring bloom: phytoplankton species composition, formation of marine snow and the role of heterotrophic dinoflagellates. J Plankton Res 18(2):133-155

Turner JT (2002) Zooplankton faecal pellets, marine snow and sinking phytoplankton blooms. Aquat Microb Ecol 27: 57-102

Viitasalo M, Rosenberg M, Heiskanen AS, Kosi M (1999) Sedimentation of copepod faecal material in the coastal northern Baltic Sea: Where did all the pellets go? Limnol Oceanogr 44:1388-1399

Wassmann P (1998) Retention versus export food chains: processes controlling sinking loss from marine pelagic systems. Hydrobiologia 363:29-57

Wassmann P, Hansen L, Andreassen IJ, Riser CW, Urban-Rich J (1999) Distribution and sedimentation of faecal pellets on the Nordvestbanken shelf, northern Norway, in 1994. Sarsia 84:239-252

Welschmeyer NA, Lorenzen CJ (1985) Chlorophyll budgetszooplankton grazing and phytoplankton growth in a temperate fjord and the Central Pacific Gyres. Limnol Oceanogr 30:1-21

Yentsch CS, Menzel DW (1963) A method for the determination of phytoplankton chlorophyll phaeophytin by fluorescence. Deep-Sea Res 10:221-231

Submitted: December 3, 2004; Accepted: October 19, 2005 Proofs received from author(s): March 22, 2006 